\title{
Reliability Estimation for Multiunit Nuclear and Fossil-Fired Industrial Energy Systems
}

\author{
W. G. Sullivan \\ J. V. Wilson \\ O. H. Klepper
}

\section{OAK RIDGE NATIONAL LABORATORY}




\section{DISCLAIMER}

This report was prepared as an account of work sponsored by an agency of the United States Government. Neither the United States Government nor any agency Thereof, nor any of their employees, makes any warranty, express or implied, or assumes any legal liability or responsibility for the accuracy, completeness, or usefulness of any information, apparatus, product, or process disclosed, or represents that its use would not infringe privately owned rights. Reference herein to any specific commercial product, process, or service by trade name, trademark, manufacturer, or otherwise does not necessarily constitute or imply its endorsement, recommendation, or favoring by the United States Government or any agency thereof. The views and opinions of authors expressed herein do not necessarily state or reflect those of the United States Government or any agency thereof. 


\section{DISCLAIMER}

Portions of this document may be illegible in electronic image products. Images are produced from the best available original document. 


\section{Printed in the United States of America. Available from National Technical Information Service \\ U.S. Department of Commerce 5285 Port Royal Road, Springfield, Virginia 22161 \\ Price: Printed Copy $\$ 5.00$; Microfiche $\$ 3.00$}

This report was prepared as an account of work sponsored by the United States Government. Neither the United States nor the Energy Research and Development Administration/United States Nuclear Regulatory Commission, nor any of their employees, nor any of their contractors, subcontractors, or their employees, makes any warranty, express or implied, or assumes any legal liability or responsibility for the accuracy, completeness or usefulness of any information, apparatus, product or process disclosed, or represents that its use would not infringe privately owned rights. 
Contract No. W-7405-eng-26

Engineering Technology Division

RELIABILITY ESTIMATION FOR MULTIUNIT NUCLEAR AND FOSSIL-FIRED INDUSTRIAL ENERGY SYSTEMS

W. G. Sullivan J. V. Wilson

O. H. Klepper

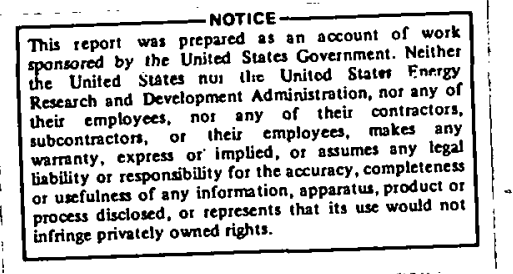

Manuscript Completed - June 29, 1977

Date Published - August 1977

Prepared by the

OAK RIDGE NATIONAL LABORATORY

Oak Ridge, Tennessee 37830

operated by

UNION CARBIDE CORPORATION

for the

ENERGY RESEARCH AIND DEVELOPMEN'I ALMINISTRATION

DISTRIBUTION OF THIE DOCUMENT IS UNLIMITED 


\section{THIS PAGE}

WAS INTENTIONALLY

LEFT BLANK 
CONTENTS

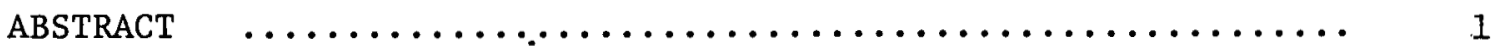

1. INTRODUCTION $\ldots \ldots \ldots \ldots \ldots \ldots \ldots \ldots \ldots \ldots \ldots \ldots \ldots \ldots \ldots \ldots \ldots$

2. REACTOR AND BOILER RELIABILITY DATA $\ldots \ldots \ldots \ldots \ldots \ldots \ldots \ldots$

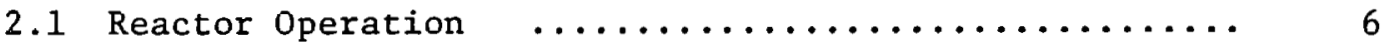

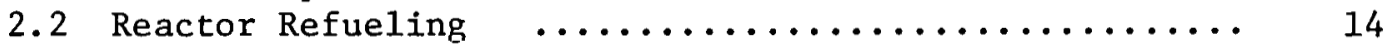

2.3 Reactor Reliability vs Unit Size and Age ......... 17

2.4 Reliability of Fossil-Fired Boilers ............. 20

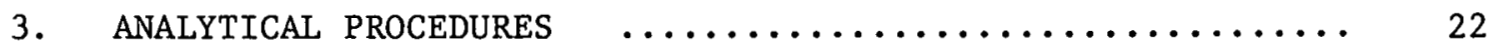

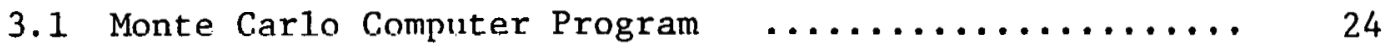

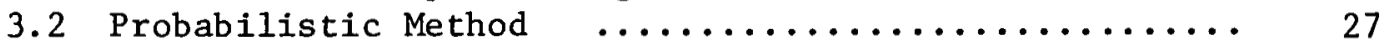

4. APPLICATION OF THE METHODOLOGY $\ldots \ldots \ldots \ldots \ldots \ldots \ldots \ldots \ldots \ldots . \ldots \ldots$

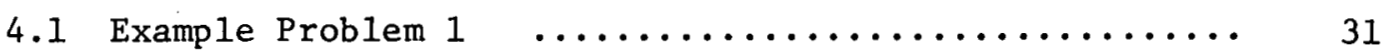

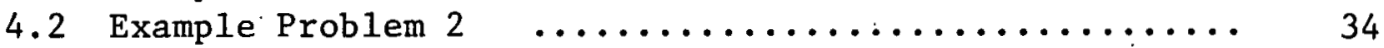

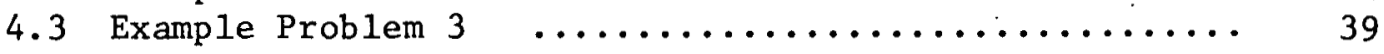

5. SUMMARY AND CONCLUSIONS $\ldots \ldots \ldots \ldots \ldots \ldots \ldots \ldots \ldots \ldots \ldots \ldots$

APPENDIX A. NUCLEAR SYSTEMS FOR INDUSTRIAL PROCESS

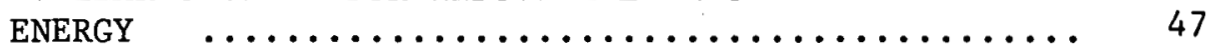

APPENDIX B. GLOSSARY FROM OPERATING UNITS STATUS REPORT

LICENSED OPERATING REACTORS $\ldots \ldots \ldots \ldots \ldots \ldots \ldots \ldots . \ldots \ldots$

APPENDIX C. DEFINITIONS OF .TERMS USED IN THE ANNUAL REPORTS

ON EQUIPMEN'T AVAILABILITY PUBLISHED BY EEI ..... 57

APPENDIX D. DIFFERENCES IN DEFINITIONS USED IN NRC AND EEI

DATA BASES

REFERENCES 


\title{
RELIABILITY ESTIMATION FOR MULTIUNIT NUCLEAR AND FOSSIL-FIRED INDUSTRIAL ENERGY SYSTEMS*
}

\author{
W. G. Sullivant J. V. Wilson \\ 0. H. Klepper
}

\begin{abstract}
As petroleum-based fuels grow increasingly scarce and costly, nuclear energy may become an important alternative source of industrial energy. Initial applications would most likely include a mix of fossil-fired and nuclear sources of process energy. A means for determining the overall reliability of these mixed systems is a fundamental aspect of demonstrating their feasibility to potential industrial users.

Reliability data from nuclear and fossil-fired plants are presented, and several methods of applying these data for calculating the reliability of reasonably complex industrial energy supply systems are given. Reliability estimates made under a number of simplifying assumptions indicate that multiple nuclear units or a combination of nuclear and fossilfired plants could provide adequate reliability to meet industrial requirements for continuity of service.
\end{abstract}

\section{INTRODUCTION}

Approximately $40 \%$ of the annual energy consumption in the United States is utilized by industrial processes, and about $40 \%$ of this is used to raise process steam. In 1971, approximately $75 \%$ of the industrial energy requirements were satisfied with direct fuel use of coal, oil, and natural gas. ${ }^{1}$ However, uncertainties associated with future availabilities of these fuels create problems for large consumers of process steam that plan to replace oil- and gas-fired boilers with coalfired units and/or nuclear steam supply systèms. One certainty is the knowledge that oil and natural gas wi.1. not be abundant sources of energy in the future. Therefore, it seems reasonable that coal and nuclear, two fuels with a long-term resource base, be considered as a1ternative energy sources.

*The helpful suggestions by R. L. Scott of the Nuclear Safety Information Center are much appreciated.

tUniversity of Tennessee. 
The purpose of this report is (1) to present and illustrate procedures for calculating the reliability of multiunit nuclear and fossilfired industrial energy systems; and (2) to determine from these preliminary calculations if industrial steam reliability requirements are likely to be met by multiunit nuclear steam sources or by a combination of nuclear and fossil-fired units. This information may be of particular interest to industries that are seeking alternative sources of energy. Because of the potential need for nuclear steam-generation systems to supplement and/or replace oil- and gas-fired sources of industrial steam, a means of determining the overall reliability of these "mixed" systems is a fundamental aspect of demonstrating their feasibility. Reliability here denotes the percent of clock time that a steam-supply system is serviceable and can satisfy the scheduled production requirements of an industrial plant. For purposes of the present report, this definition has been adopted as the primary meaning of "reliability" in the context of industrial production.

For large chemical plants, petroleum refineries, or steel mills, there is no single index of steam-supply reliability in widespread use because the various definitions currently being utilized are indirative of relative plant performance. The indicators vary with time, with manutacturing process, with companies, and with production goals of a particular plant. Several other indicators of the reliability of a steam-supply system are being widely used in the electric utility industry (such as capacity factor, availability, and forced outage rate); these are defined in Section 4, which gives representative data for several example problems.

An earlier report ${ }^{2}$ presented results of a nationwide study aimed toward quantifying the reliability of present-day steam=supply eyctcms. Major findings of this study for the chemical and petrolcum refining industries are shown in Tables 1 and 2. Line $N$ of Table 1 shows that steam-supply systems of chemical plants in the survey were unreliable an average of $1.96 \%$ of the service time (about $98 \%$ re1iable). Petroleum refineries supply systems were approximately $92 \%$ reliable (100 - average value of line $\mathrm{N}$ in Table 2). These figures indicate the historical steamsupply reliabilities that will be used as benchmarks against which proposed 
Table 1. Process steam system capacity, ${ }^{a}$ consumption rate,

and reliability for chemical plants

\begin{tabular}{|c|c|c|c|c|c|c|c|c|c|c|c|c|c|c|c|c|c|c|}
\hline \multirow{2}{*}{\multicolumn{2}{|c|}{ Item of data }} & \multicolumn{17}{|c|}{ Plant } \\
\hline & & 1 & 2 & $3^{\mathrm{b}}$ & 4 & 5 & 6 & 7 & 8 & 9 & 10 & 11 & 12 & 13 & 14 & 15 & 16 & 17 \\
\hline A. & $\begin{array}{l}\text { Average Installed capacity, } \\
10^{3} \text { lb of steam } / \mathrm{hr}\end{array}$ & 4360 & 2440 & 800 & 1595 & $1: 00$ & 1200 & 1220 & 690 & 780 & 805 & 525 & 360 & 220 & $320^{c}$ & $300^{d}$ & 192 & 144 \\
\hline в. & $\begin{array}{l}\text { Average on-line capacity, } \\
10^{3} \mathrm{lb} \text { of steam } / \mathrm{hr}\end{array}$ & 3700 & 2320 & 758 & 1450 & 1475 & 1190 & 1155 & 659 & 670 & 764 & 500 & 330 & 212 & 265 & 280 & 175 & 136 \\
\hline c. & $\begin{array}{l}\text { Average on-line capacity, } \\
\text { as percentage of } \mathrm{A}\end{array}$ & 84.8 & 95.1 & 94.8 & 91.0 & 86.8 & 99.2 & 94.7 & 95.5 & 85.9 & 94.9 & 95.2 & 9.17 & .96 .2 & 82.8 & 93.3 & 91.1 & 94.4 \\
\hline D. & $\begin{array}{l}\text { Average actual steam usage, } \\
10^{3} \mathrm{lb} / \mathrm{hr}\end{array}$ & 3300 & 1900 & 390 & 1170 & 1160 & 960 & 917 & 565 & 550 & 520 & $\angle 80$ & 270 & 175 & 164 & 116 & 100 & 65 \\
\hline E. & $\begin{array}{l}\text { Average scheduled steam } \\
\text { usage, } 10^{3} 1 \mathrm{~b} / \mathrm{hr}\end{array}$ & 3300 & 1900 & 400 & 1203 & .1230 & 960 & 917 & 580 & 600 & 530 & $\angle 80$ & 280 & 175 & 164 & 116 & 100 & 65 \\
\hline F. & $\begin{array}{l}\text { Average actual steam usage, } \\
\text { as percentage of B }\end{array}$ & 89.2 & 31.9 & 51.5 & 80.7 & 78.6 & 80.7 & 79.4 & 85.7 & 82.1 & 68.1 & 96.0 & 84.8 & 82.5 & 61.9 & 41.4 & 57.1 & 47.8 \\
\hline G. & $\begin{array}{l}\text { Average safety margin, } \\
\text { item B mincs item D }\end{array}$ & 400 & $¥ 20$ & 368 & 280 & $3: 5$ & 230 & 238 & 94 & 120 & 244 & 20 & 50 & 37 & 101 & 164 & 75 & 71 \\
\hline $\begin{array}{l}\text { H. } \\
\text { I. }\end{array}$ & $\begin{array}{l}\text { Average safety margin, } \\
\text { as percentage of } D \\
\text { Largest untt on } 1 \text { ne: }\end{array}$ & 12.1 & 22.1 & 94.4 & 23.9 & $2 ? .2$ & 24.0 & 25.9 & 16.6 & 21.8 & 46.9 & 4.2 & 18.5 & 21.1 & 61.6 & 141.0 & 75.0 & 109.2 \\
\hline & $\begin{array}{l}10^{3} \text { lb of steam/hr } \\
\text { Average Fercentage of } B\end{array}$ & $\begin{array}{l}430 \\
11.6\end{array}$ & $\begin{array}{l}400 \\
17.2\end{array}$ & $\begin{array}{l}400 \\
52.8\end{array}$ & $\begin{array}{l}200 \\
13.8\end{array}$ & $\begin{array}{l}550 \\
3 ? .3\end{array}$ & $\begin{array}{l}250 \\
21.0\end{array}$ & $\begin{array}{l}267 \\
23.1\end{array}$ & $\begin{array}{l}230 \\
34.9\end{array}$ & $\begin{array}{l}125 \\
18.7\end{array}$ & $\begin{array}{l}350 \\
45.8\end{array}$ & $\begin{array}{l}175 \\
35.0\end{array}$ & $\begin{array}{l}100 \\
30.3\end{array}$ & $\begin{array}{l}100 \\
47.2\end{array}$ & $\begin{array}{l}125 \\
4 i .2\end{array}$ & $\begin{array}{l}150 \\
53.6\end{array}$ & $\begin{array}{l}72 \\
41.1\end{array}$ & $\begin{array}{l}60 \\
44.1\end{array}$ \\
\hline J. & $\begin{array}{l}\text { Safety margin as percentage } \\
\text { of largest unit on-11ne (I) }\end{array}$ & 93.0 & 105.0 & 92.0 & 140.0 & 57.3 & 100.0 & 89.0 & 40.9 & 96.0 & 69.7 & 11.4 & 50.0 & 37.0 & 80.0 & 109.0 & 104.2 & 118.3 \\
\hline $\mathrm{k}$. & $\begin{array}{l}\text { Percent of time steam supply unable } \\
\text { to meet scheduled requirenents (E) } \\
\text { due to rancom equipment outages }\end{array}$ & 0.8 & 0 & 0 & 2.4 & 9.0 & 0 & 0.8 & 0 & 3.8 & 6.8 & 0 & 0 & 0 & 0 & 0 & 0.2 & 0 \\
\hline L. & $\begin{array}{l}\text { Percent of time scheduled steam pro- } \\
\text { duction (E) was curtalled due to non- } \\
\text { equipment-related outages }\end{array}$ & 0 & 0.5 & 1.4 & 0 & 2.0 & 0.5 & 0 & 1.2 & 2.0 & 0 & 0 & 1.2 & 0 & 0 & 0 & 0.8 & 0 \\
\hline м. & $\begin{array}{l}\text { Percent of time plant was completely } \\
\text { shut down for scheduled vacation or } \\
\text { plant turneround }\end{array}$ & 0 & 0 & 0 & 0 & 0 & 0 & 0 & 2.5 & 1.0 & 1.1 & 0 & 3.8 & 3.8 & 3.8 & 3.8 & 2.2 & 0 \\
\hline N. & $\begin{array}{l}\text { Total percent of time scheduled steam } \\
\text { production was curtailed (item } K+1 \text { tem L) }\end{array}$ & 0.8 & 0.5 & 1.4 & 2.4 & 11.0 & 0.5 & 0.8 & 1.2 & 5.8 & 6.8 & 0 & 1.2 & 0 & 0 & 0 & 1.0 & 0 \\
\hline
\end{tabular}

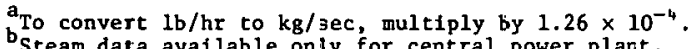

coes not include $65,000 \mathrm{tb} / \mathrm{hr}$ standby boller.

Does not include $45,000 \mathrm{lb} / \mathrm{hr}$ standby boiler. 
Table 2. Process steam system capacity, ${ }^{a}$ consumftion rate, and reliability for petroleum refineries

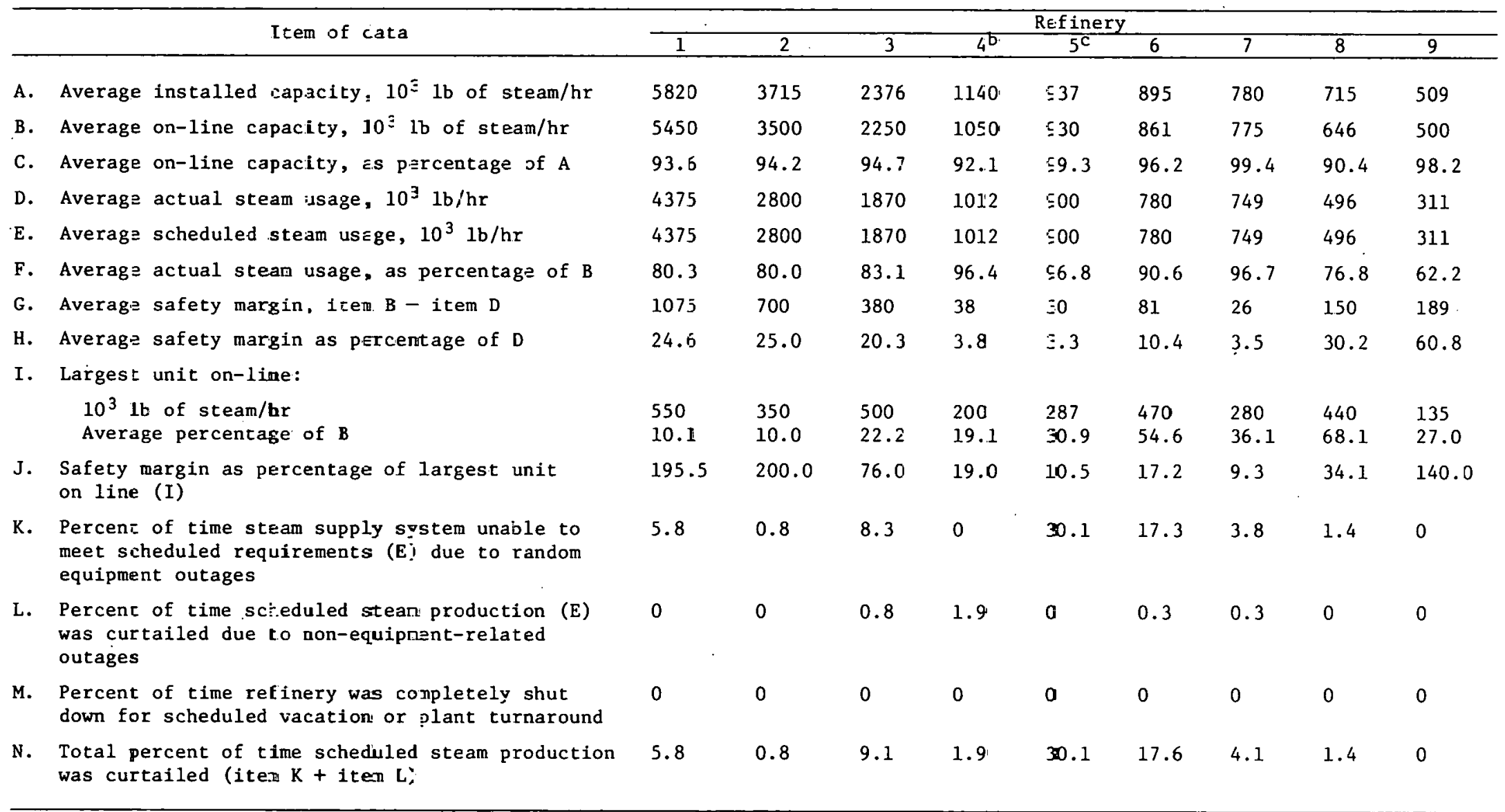

$\mathrm{a}_{\text {To }}$ convert $\mathrm{lb} / \mathrm{hr}$ to $\mathrm{kg} / \mathrm{s}$, multiply by $\mathrm{i} .26 \times 10^{-4}$.

$172,000 \mathrm{lb} / \mathrm{hr}$ purchesed stean (nameplate capacity equals $180,000 \mathrm{lb} / \mathrm{hr}$ ).

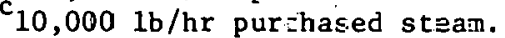


industrial energy systems can be compared. The approach used to estimate the combined reliability of multiunit steam-supply systems will take three fundamental considerations into account: (1) the total amount of steam required under normal and maximum operating conditions by individual companies and/or industrial parks, (2) the technical features of alternative configurations and nuclear and fossil units capable of satisfying industrial energy reliability requirements, and (3) the forced outage characteristics, startup times, and load-following behavior of the systems being evaluated. Technical features and costs, of various nuclear steam-supply systems are briefly discussed in Appen$\operatorname{dix}$ A. 
2. REACTOR AND BOILER RELIABILITY DATA

\subsection{Reactor Operation}

The reliablitty of nuclear reactor systems is documented in detall in a series of reports entitled Operating Units Status Report: Licensed Operating Reactors: Data for Decisions, ${ }^{3}$ which is also referred to as the NRC Gray Book. This report is issued monthly by the Nuclear Regulatory Commission (NRC) for use by the Federal Energy Adninistration (FEA), Energy Research and Development Administration (ERDA), Federal Power Commission (FPC), and other federal agencies. Detailed monthly histories of forced and scheduled outages for cummerctal reactor systems can be dem veloped from the information given in the report. Representative monthly statistics from the July 1976 report, which presents operating experience for June 1976, are shown in Tables 3 to 6 and in Fig. 1. The terms used in the NRC report are defined in Appendix B. The NRC issued an annual evaluation report for the 1973 data, ${ }^{4}$ and a report that combines the 1974 and 1975 data will be issued in the winter of 1976-77.

Power generation data and a breakdown of outage frequencies and durations appear in Tables 3 and 4. Table 3 gives various statistics for June 1976. Of particular interest here are average reactor availability factors and average forced outage rates during the month. Table 4 shows that the percent of clock time for scheduled outages in June 1976 was about twice that for forced outages; Table 5 gives the reasons for the June shutdowns. Notice that hours lost for refueling amounted to about one-third of the total hours lost. Equipment failures were the most common. reason for shutdowns, although they represent only about one-fourth of total hours lost. Additional detailed monthly statistics that high1ight reactor availabllity faccors, unit forced outage rates, etc., fnr each licensed nuclear power plant are also given in the NRC reports. The data provided in Table 6 for 13 power plants illustrate the variation in key operating statistics among plants. The daca are defined in Appendix B. Reactor data pertain to the reactor plant only; unit data refer to the performance of the reactor and its associated power conversion system. Reactor availabilities ranged from 0 to $100 \%$, while unit 
Table 3. Power generation data for commerctal nuclear power units (June 1976)

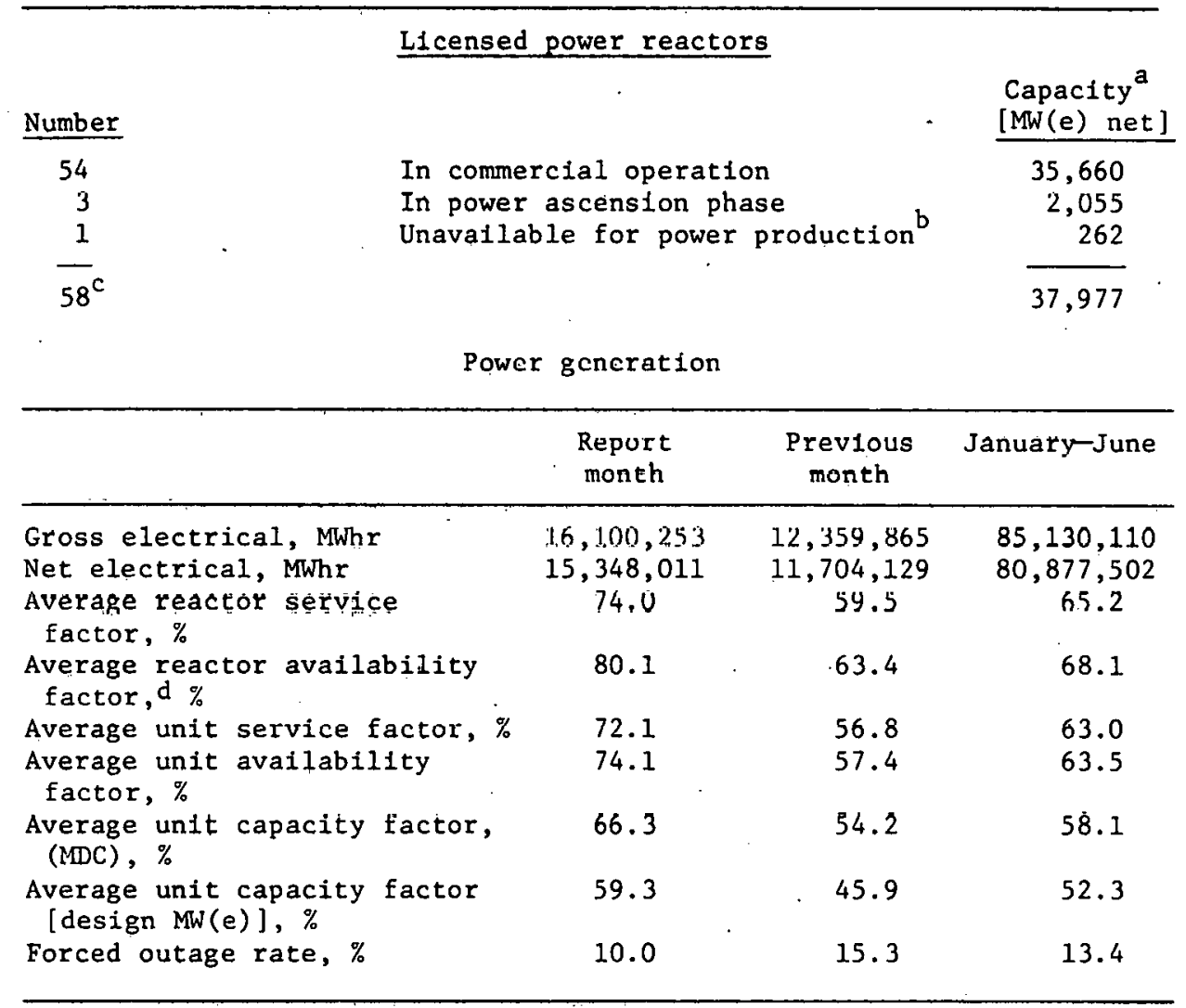

a Based on maximum dependable capacity; design capacity used if MDC not determined.

bIndian Pnint lo shut datun.

CPeach Bottoin 1 not included; belng decommissioned.

The average reactor availability factor is of interest in the present study because it indicates the fraction of the time that the reactor is available for service hours plus the reserve shutdown hour 3 divided by the gross hours in the period.

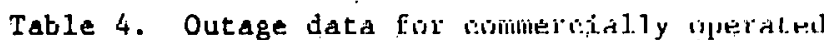
nuclear power plants (Juné 1976)

\begin{tabular}{|c|c|c|c|c|}
\hline & Number & Hours & $\begin{array}{l}\text { Pereent of } \\
\text { clock title }\end{array}$ & $\begin{array}{l}\text { Loot electricity } \\
\text { production (MWhr) }\end{array}$ \\
\hline $\begin{array}{l}\text { Forced outages during } \\
\text { month }\end{array}$ & 54 & $3,291.5$ & 8.8 & $1,727,807$ \\
\hline $\begin{array}{l}\text { Scheduled outages } \\
\text { during the month }\end{array}$ & 27 & $7,537.7$ & 19.7 & $2,931,753$ \\
\hline Total & 81 & $10,829.2$ & 28.5 & $4,659,560$ \\
\hline
\end{tabular}

${ }^{a}$ Capacity factor of 0.75 was assumed for units that did not operate : at all during the period. 
Table 5. Shutdown information for commercial nuclear power units (June 1976)

\begin{tabular}{|c|c|c|c|}
\hline \multicolumn{4}{|c|}{ Shutdowns greater than 12 hr each } \\
\hline Unit & Reason & Unit & Reason \\
\hline Arkansas 1 & $2 \mathrm{~A}$ & Nine Mile Point & B \\
\hline Big Rock Point & $\mathrm{H}$ & Oconee 2 & C \\
\hline Browns Ferry 1 & B & Peach Bottom 2 & $A, C$ \\
\hline Browns Ferry 2 & B & Pilgrim & $A, C, G$ \\
\hline Brunswick 2 & $A$ & Prairie Island 1 & $\mathrm{~A}, \mathrm{H}$ \\
\hline Connecticut Yankee & C & Prairie Island 2 & $A, B$ \\
\hline Dresden 1 & & Quad Cities 1 & B \\
\hline Dresden 2 & $A, B$ & Rancho Saco & A \\
\hline Duane Arnold & B & Surry 2 & C \\
\hline Fitzpatrick & $A, 2 G$ & Trojan & B \\
\hline Hatch 1 & A & Turkey Point 3 & $2 \mathrm{~A}$ \\
\hline Indian Point 2 & C & Turkey Point 4 & $2 \mathrm{~A}, \mathrm{C}$ \\
\hline LaCrosse & $\mathrm{D}$ & Vermont Yankee & $\mathrm{C}, \mathrm{G}$ \\
\hline Maine Yankee & A & Zion 1 & $A, C, H$ \\
\hline Montice1lo & B & Zion 2 & $4 B, C$ \\
\hline
\end{tabular}

Reasons for shutdown

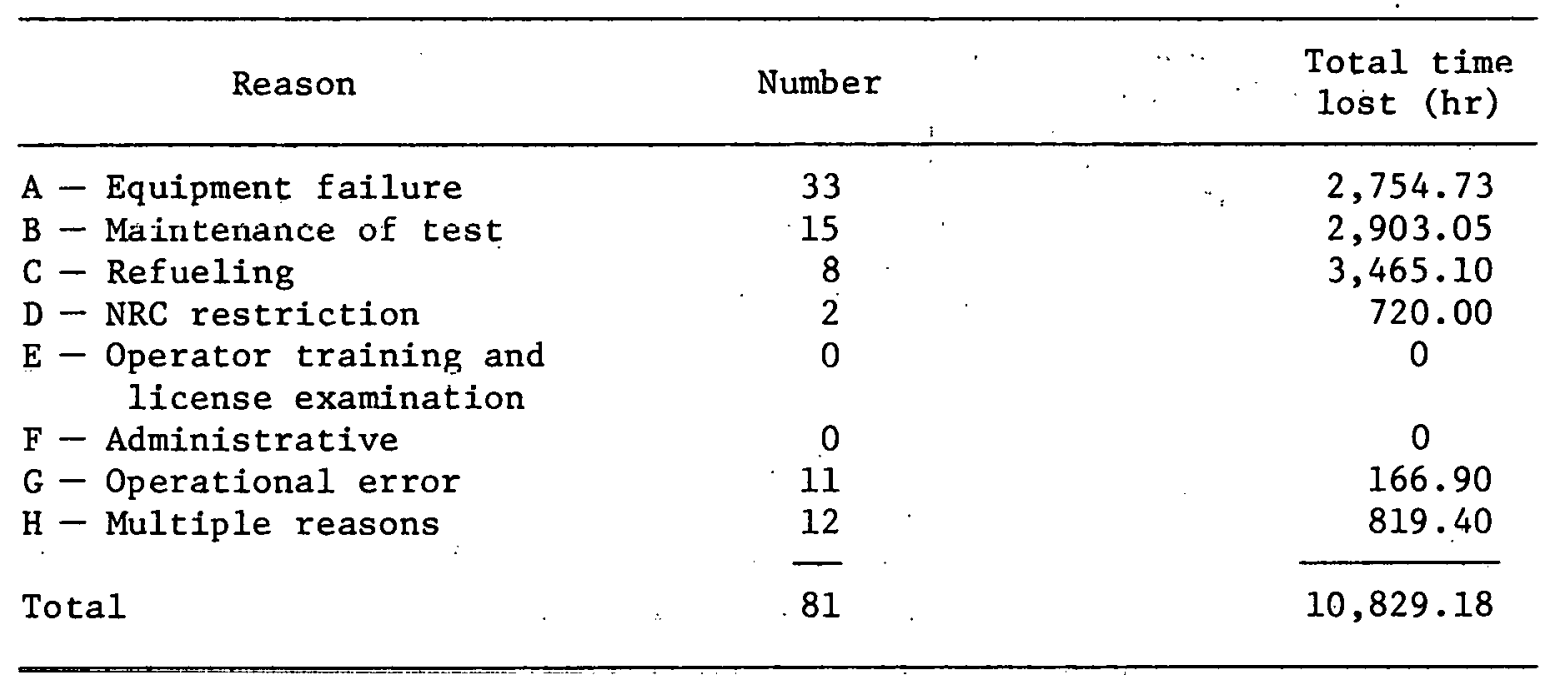

forced outage rates ranged from 0 to $18.6 \%$. Figure 1 shows considerable variation in average unit forced outage rates and availability factors during the first six months of 1976. 
Table 6. Selected monthly un1t data as of June 30, 1976

\begin{tabular}{|c|c|c|c|c|c|c|c|c|c|c|c|c|c|}
\hline $\begin{array}{c}\text { Un1t name! } \\
\text { utility }\end{array}$ & $\begin{array}{l}\text { Unit s1 } \\
\text { [MW(e)] } \\
\text { type }\end{array}$ & & & $\begin{array}{l}\text { Maximum } \\
\text { dependable } \\
\text { capac1ty }\end{array}$ & $\begin{array}{l}\text { Reactor } \\
\text { service } \\
\text { factor } \\
\quad(\%)\end{array}$ & $\begin{array}{l}\text { Reactor } \\
\text { avallabllity } \\
\text { factor } \\
(\%)\end{array}$ & $\begin{array}{l}\text { Unit } \\
\text { service } \\
\text { factor } \\
(\%)\end{array}$ & $\begin{array}{c}\text { Un1t } \\
\text { availab11 } \\
\text { factor } \\
(\%)\end{array}$ & 11 ty & $\begin{array}{l}\text { Unit } \\
\text { capac1ty } \\
\text { factor } \\
(\mathrm{MDC})(\%)\end{array}$ & $\begin{array}{l}\text { Unit } \\
\text { capacity } \\
\text { factor } \\
\text { (des1gn) } \\
(\%)\end{array}$ & $\begin{array}{l}\text { Un1t } \\
\text { forced } \\
\text { outage } \\
\text { rate } \\
(\%)\end{array}$ & Summary \\
\hline $\begin{array}{l}\text { Arkansas } 1 \\
\text { Arkansas Power } \\
\text { \& Light }\end{array}$ & $\begin{array}{l}850 \\
\text { PWR }\end{array}$ & & & 836 & 12.8 & 38.1 & 6.3 & 6.3 & $\therefore$ & 2.8 & 2.8 & 2.8 & $\begin{array}{l}\text { Unit started up after removal of the } \\
\text { survelllance tubes. An additional } \\
\text { shutdown was experienced to replace } \\
\text { burned exciter bearing and repair } \\
\text { stator. }\end{array}$ \\
\hline $\begin{array}{l}\text { Beaver Valley } 1 \\
\text { Duquesne Light Co. }\end{array}$ & $\begin{array}{l}852 \\
\text { PWR }\end{array}$ & & $\therefore$ & 852 & $\mathrm{~N} / \mathrm{A}$ & $\mathrm{N} / \mathrm{A}$ & $\mathrm{N} / \mathrm{A}$ & $\mathrm{N} / \mathrm{A}$ & & $\mathrm{N} / \mathrm{A}$ & $\mathrm{N} / \mathrm{A}$ & $\mathrm{N} / \mathrm{A}$ & $\begin{array}{l}\text { Initial criticality achieved at } 6: 45 \\
\text { p.m. } 05-10-76 \text {. ASLB issued license } \\
\text { for } 35 \% \text { rated power on } 05-28-76 \text {. The } \\
\text { unit is in Mode } 1 \text {, operation, and } \\
\text { performing powar tcoting. ASLB is- } \\
\text { sued full-power license } 07-02-76 \text {. }\end{array}$ \\
\hline $\begin{array}{l}\text { Big Rock Point } 1 \\
\text { Consumers Power }\end{array}$ & $\begin{array}{r}72 \\
\text { BWR }\end{array}$ & & & 71 & 4.8 & 4.8 & 0.0 & 0.0 & & 0.0 & 0.0 & 0.0 & $\begin{array}{l}\text { Core loaded 05-02-76, spray head in- } \\
\text { stalled 05-12-76. Component leak } \\
\text { rate completed. Startup scheduled } \\
07-07-76 \text {. Plant life exemption and } \\
\text { new license received. Physics test- } \\
\text { ing completed } 06-17-76 \text {. }\end{array}$ \\
\hline $\begin{array}{l}\text { Browns Ferry } 1 \\
\text { Tennessee Va1ley } \\
\text { Authority }\end{array}$ & $\begin{array}{r}1065 \\
\text { BWR }\end{array}$ & & & 1065 & 0.0 & 100.0 & .0 .0 & 0.0 & & 0.0 & 0.0 & 100.0 & $\begin{array}{l}\text { License was amended to permit fuel } \\
\text { loading only on } 07-02-76 \text {. Fuel load- } \\
\text { ing began } 07-04-76 \text {. }\end{array}$ \\
\hline $\begin{array}{l}\text { Browns Ferry } 2 \\
\text { Tennessee Valley } \\
\text { Authority }\end{array}$ & $\begin{array}{r}1065 \\
\text { BWR }\end{array}$ & & & 1065 & $\begin{array}{l}0.0 \\
: \quad .\end{array}$ & 100.0 & 0.0 & 0.0 & & 0.0 & 0.0 & 100.0 & $\begin{array}{l}\text { TVA considers unit } 2 \text { ready for re- } \\
\text { fueling. }\end{array}$ \\
\hline $\begin{array}{l}\text { Brunswick } 2 \\
\text { Carolina Power } \\
\text { \& Light }\end{array}$ & $\begin{array}{l}821 \\
\text { BWR }\end{array}$ & . & & 790 & 97.6 & 97.6 & 96.2 & 96.2 & & 64.0 & 61.6 & 3.8 & \\
\hline $\begin{array}{l}\text { Calvert Cliffs } 1 \\
\text { Baltimore Gas \& } \\
\text { Electric Co. }\end{array}$ & $\begin{array}{l}845 \\
\text { PWR }\end{array}$ & . & & 800 & 99.2 & 100.0 & 99.0 & 99.0 & & 98.7 & 93.5 & 1.0 & $\begin{array}{l}\text { An order for modification of license } \\
\text { was issued } 06-17-76 \text { to add the pro- } \\
\text { vision that peak linear neat gener- } \\
\text { ation be limited to } 13.9 \mathrm{~kW} / \mathrm{ft} \text {. }\end{array}$ \\
\hline $\begin{array}{l}\text { Connecticut Yankee } \\
\text { Cumimeticut Yankec } \\
\text { Atomic Power Co. }\end{array}$ & $\begin{array}{l}575 \\
\text { PWR }\end{array}$ & & & 540 & 0.0 & 0.0 & 0.0 & 0.0 & & 0.0 & 0.0 & 0.0 & $\begin{array}{l}\text { Low physics testing completed } 07-05- \\
76 \text {. Unit expected to be at } 100 \% \\
\text { puwer by } 07-09-76 \text {. }\end{array}$ \\
\hline $\begin{array}{l}\text { Cook } 1 \\
\text { Indiana \& Michigan } \\
\text { Power Co. }\end{array}$ & $\begin{array}{r}1090 \\
\text { PWR }\end{array}$ & .1 & & 931 & 98.7 & 98.7 & 98.5 & 98.5 & : & 96.2 & 94.9 & 1.5 & $\begin{array}{l}\text { Unit operated at } 100 \% \text { of rated power } \\
\text { for testing. }\end{array}$ \\
\hline $\begin{array}{l}\text { Cooper Nuclear Station } \\
\text { Nebraska Public Power } \\
\text { District }\end{array}$ & on 778 . & . & & 764 & 100.0 & .100 .0 & 100.0 & 100.0 & & 67.0 & 65.8 & 0.0 & $\begin{array}{l}\text { Unit generation limited by MAPLHGR } \\
\text { due to core plugging. }\end{array}$ \\
\hline $\begin{array}{l}\text { Dresden } 1 . \\
\text { Commonwealth Edtson }\end{array}$ & $\begin{array}{l}200 \\
\text { BWR }\end{array}$ & & . & 207 & 89.7 & 89.7 & 88.2 & 88.2 & $\ldots$ & 64.6 & 63.6 & 0.0 & $\begin{array}{l}\text { Load was limited due to fuel re- } \\
\text { strictions of MAPLHGR limits. }\end{array}$ \\
\hline $\begin{array}{l}\text { Dresden } 2 \\
\text { Commonwealth Edison }\end{array}$ & $\begin{array}{l}809 \\
\text { BWP }\end{array}$ & $\cdot$ & & 794 & 94.4 & 94.4 & 87.6 & 87.6 & & 74.5 & 71.1 & 6.6 & $\begin{array}{l}\text { Off-gas explosion in "A" SJAE; oper- } \\
\text { ation continued using "B" SJAE while } \\
\text { rupture diaphragms were replaced. }\end{array}$ \\
\hline $\begin{array}{l}\text { Dresden }-3 \\
\text { Commonwealth }\end{array}$ & $\begin{array}{l}809 \\
\text { BWR }\end{array}$ & & & 794 & 100.0 & 100.0 & 100.0 & 100.0 & & 71.1 & 67.9 & 0.0 & $\begin{array}{l}\text { " } 3 \mathrm{C} " \text { condensate booster pump Impel- } \\
\text { ler was modified and tested. " } 3 \mathrm{~A} " \\
\text { and " } 3 \mathrm{~B} \text { " w111 be modified this } \\
\text { summer. }\end{array}$ \\
\hline
\end{tabular}




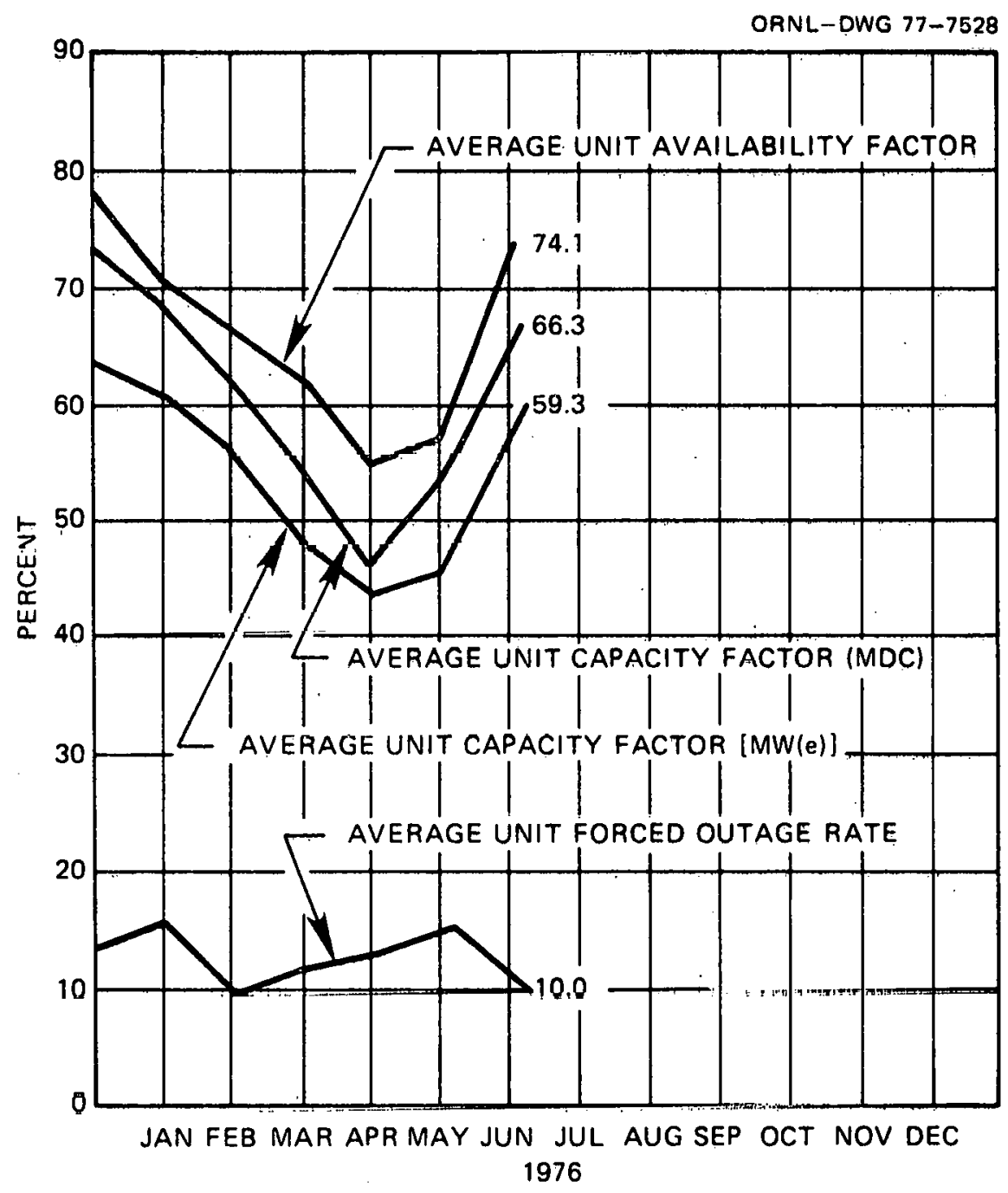

Fig. 1. Reliability indices for commercial nuclear power units (June 1976). From Ref. 3.

The capacity factor is another commonly uoed indicator ar pulper plant veliability. Figure 2 lists average reductions in capacity factor (defined in Appendix $C$ ) for seven nuclear plants, 5 which represente a good cross section of industry. These include four pressurized-water reactors (PWRs) and three boiling-water reactors (BWRs); the ages of these reactors vary from 2.5 to 12.0 years and the average capacity is 512 MW(e) net. There was considerable variation in performance among units; note that about $14.4 \%$ of the reductions in capacity factor resulted from causes unrelated to reliability. Almost half of these 
ORNL -.-DWG 77--7529

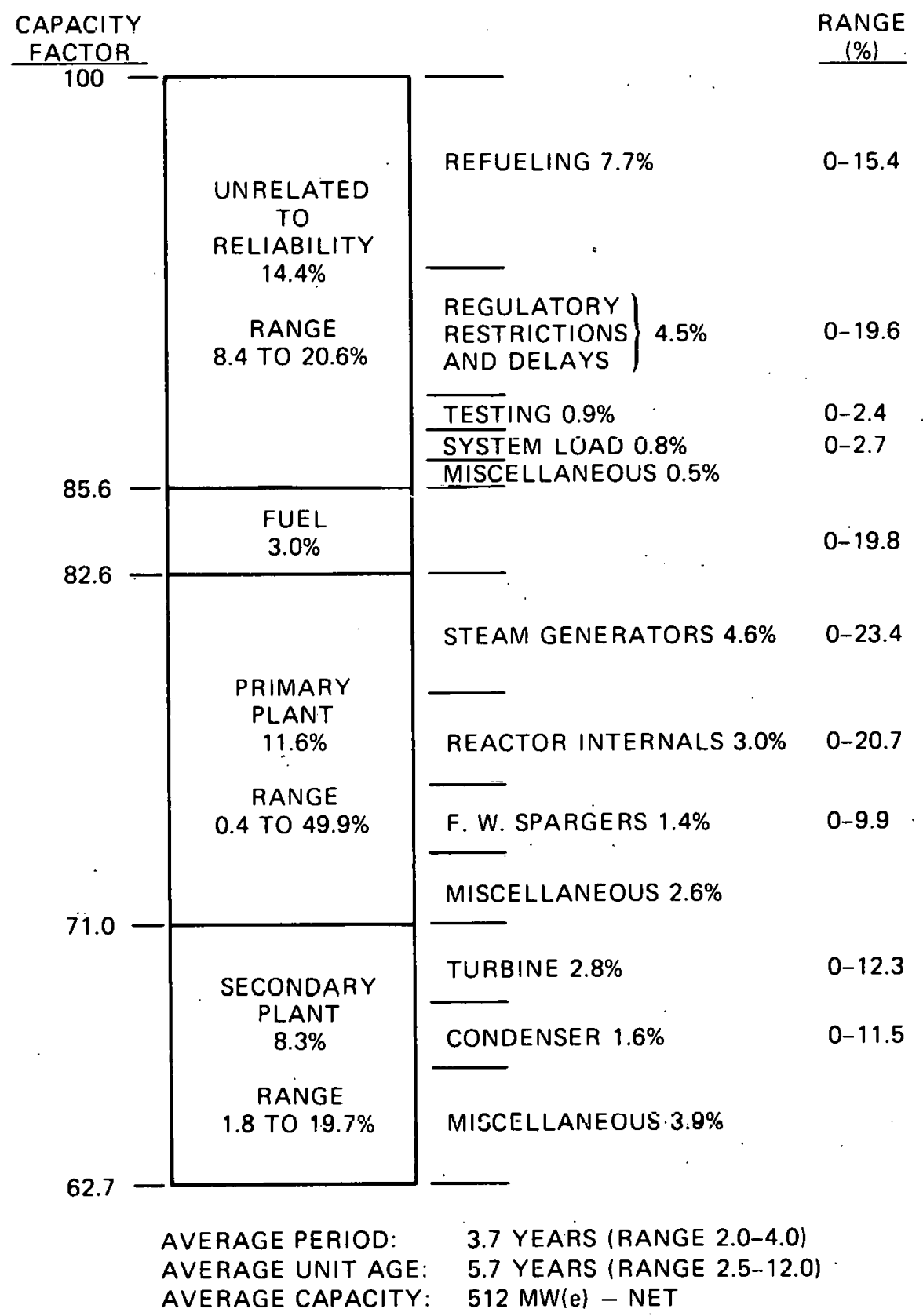

Fig. 2. Average reductions in capacity factor for seven units (4 BWRs). From Ref. 5. 
resulted from normal refueling. Fuel and primary plant difficulties accounted for a $14.6 \%$ reduction in average capacity factor, and the secondary plant accounted for $8.3 \%$. The total reduction in capacity factor was $37.3 \%$.

Reliability data from industry sources are compiled by the Edison Electrical Institute (EEI) and published annually; their reports are available about nine months after the reporting period. 6 Many of the EEI statistics will be useful in determining the overall reliability of hybrid (mixed nuclear and fossil) systems that may be used by manufacturing industries to produce process energy. For example, a summary of average forced and scheduled outage durations for fossil-fueled and nuclear power plants is give in Table 7. Definitions of terms included in the reports are given in Appendix C. Differences between these definitions and those of Ref. 3 are discussed in Appendix D.

Table 7. Average forced and scheduled outage durations for fossil-fired and nuclear power plants ${ }^{6}$

\begin{tabular}{|c|c|c|c|}
\hline \multirow[b]{2}{*}{$\begin{array}{l}\text { Size of } \\
\text { plant } \\
\text { (MW) }\end{array}$} & \multicolumn{2}{|c|}{ Fornnd nutngrn } & \multirow{2}{*}{$\begin{array}{l}\text { Mnintenane aind plamulud } \\
\text { outage durations } \\
\text { (tims of outage) } \\
\text { (months) }\end{array}$} \\
\hline & $\begin{array}{c}\mathrm{EFOR}^{\mathrm{a}} \\
(?)\end{array}$ & $\begin{array}{l}\text { Duration of } \\
\text { nutage } \\
\text { (days) }\end{array}$ & \\
\hline
\end{tabular}

Fossil

$\begin{array}{crrr}60-89 & 2.8 & 2.2 & 0.8 \\ 90-129 & .4 .5 & 1.9 & 1.0 \\ 130-199 & 4.8 & 1.9 & 1.0 \\ 200-109 & 7.6 & 2.3 & 1.2 \\ 390-599 & 12.9 & 2.6 & 1.4 \\ \text { 6nก ир } & 2.1 .9 & 2.9 & 1.4 \\ \Lambda \perp \text { nuclear } & 15.6 & 3.4 & 1.6\end{array}$

$a_{E F O R}-$ equivalent forced outage rate - includes the effects of forced partial outages as well as full forced outages. In many cases the forced outage rate is based solely on full forced outages. Based on this viewpoint, FORs are generally about two-thirds of the EFOR for large nuclear and fossil-fired units. 
Additional information regarding nuclear steam supply system (NSSS) forced outage rates relevant to the present study is quoted below: ${ }^{7}$

"As of March 1975, nuclear units had been in a forced outage state due to equipment failure for approximately $10 \%$ of their total commercial service life. This amounted to about 22 unit years of forced outage. Nearly 11 of these outage years were accounted for by approximately 70 major incidents (greater than 500 hour outage duration) in large plants. The remaining 11 unit years of forced outage are attributable to several thousand incidents. As a rough rule-of-thumb, $40 \%$ of the incidents are in nuclear-related elements; the remaining $60 \%$ are balance-ofplant items."

The Electric Power Research Institute (EPRI) conducted detailed studies of commercial BWRs and PWRs for the period July 1974 through March 1975. Findings of the studies indicated that nuclear units undergo three to five scheduled outages per year, exclusive of those for refueling, and last 80 to $100 \mathrm{hr}$ per incident. ${ }^{7}$ The number of annual forced outages at nuclear units included in the survey ranged from 11 to 15 . The average times of forced outages were 68 and $57 \mathrm{hr}$ for BWRs and PWRs, respectively.

Reactor availabilities and forced outage rates can also be obtained from the EEI reports. Reliability data for nuclear units of all sizes. are given in Table 8 , along with the average time between forced outages for the reactor. This quantity, which is referred to as "mean time between failures" (MTBF), is of particular interest in this study. The MTBF for nuclear steam-supply systems. (NSSS) was $1969 \mathrm{hr}$ for the period 1965 through 1974. Definitions of terms are given in Appendix C.

Other.sources of data on this subject inçlude Nuclear Engineering International (March 1975), Nuclear Safety (March-April 1975), and Nuclear Power Growth (WASH 1139-74). However, the most up-to-date source is the NRC monthly report. ${ }^{3}$

As indicated in Fig. 2, one of the major influences on steam availability from nuclear reactors is the refueling time; the major influences on reliability of a reactor are the size and age of the system. In selecting representative data for example problems that demonstrate the evaluation procedure, these two subjects are examined further at this point. 
Table 8. Availability and forced outage rates of major components in nuclear units of all sizes ${ }^{a}$

\begin{tabular}{lccc}
\hline Component & $\begin{array}{c}\text { Operating } \\
\text { availability }(\%)\end{array}$ & $\begin{array}{c}\text { Forced outage } \\
\text { rate }(\%)\end{array}$ & $\begin{array}{c}\text { Mean time between } \\
\text { forced outages (hr) }\end{array}$ \\
\hline Reactor & 81.5 & 6.5 & 1,969 \\
Turbine & 92.6 & 3.2 & 4,146 \\
Condenser & 97.6 & 0.5 & 14,181 \\
Generator & 97.6 & 0.8 & 27,180 \\
Other & 97.9 & 1.2 & 4,773 \\
Total unit & 75.6 & 11.4 & 942 \\
\hline
\end{tabular}

${ }^{a}$ Data bace consiats of 43 units with combined unll years equal to 123. Source: Ref. 6 .

\subsection{Reactor Refueling}

A study by EPRI shows the relative effect that scheduled outages for refueling have on nuclear power plant availability. ${ }^{7}$ Curve $A$ in Fig. 3 , which illustrates the cumulative availability (as defined in Appendix $C$ ) of nuclear units between refueling periods, yields some perspective on how well nuclear units perform between major srheduled service outages. Achieved values in excess of $95 \%$ represent outstanding performance. The present impact of refueling on availability is suggested hy romparing curves $A$ and $B$, the latter of which includes the impact of refueling. Care must be taken in interpreting these data since the industry as a whole is not in "refueling equilibrium." A large number of units that have not undergone first or second refuelings are combined with units that have undergone extensive refuelings and others whose limited refueling downtime is masked by a discrete long-term outage. Mature units have been unavailable 13 to $17 \%$ of their total life for refueling.

In general, it has been found that the average reliability of nuclear power plants improves after the unit has been refueled twice. 


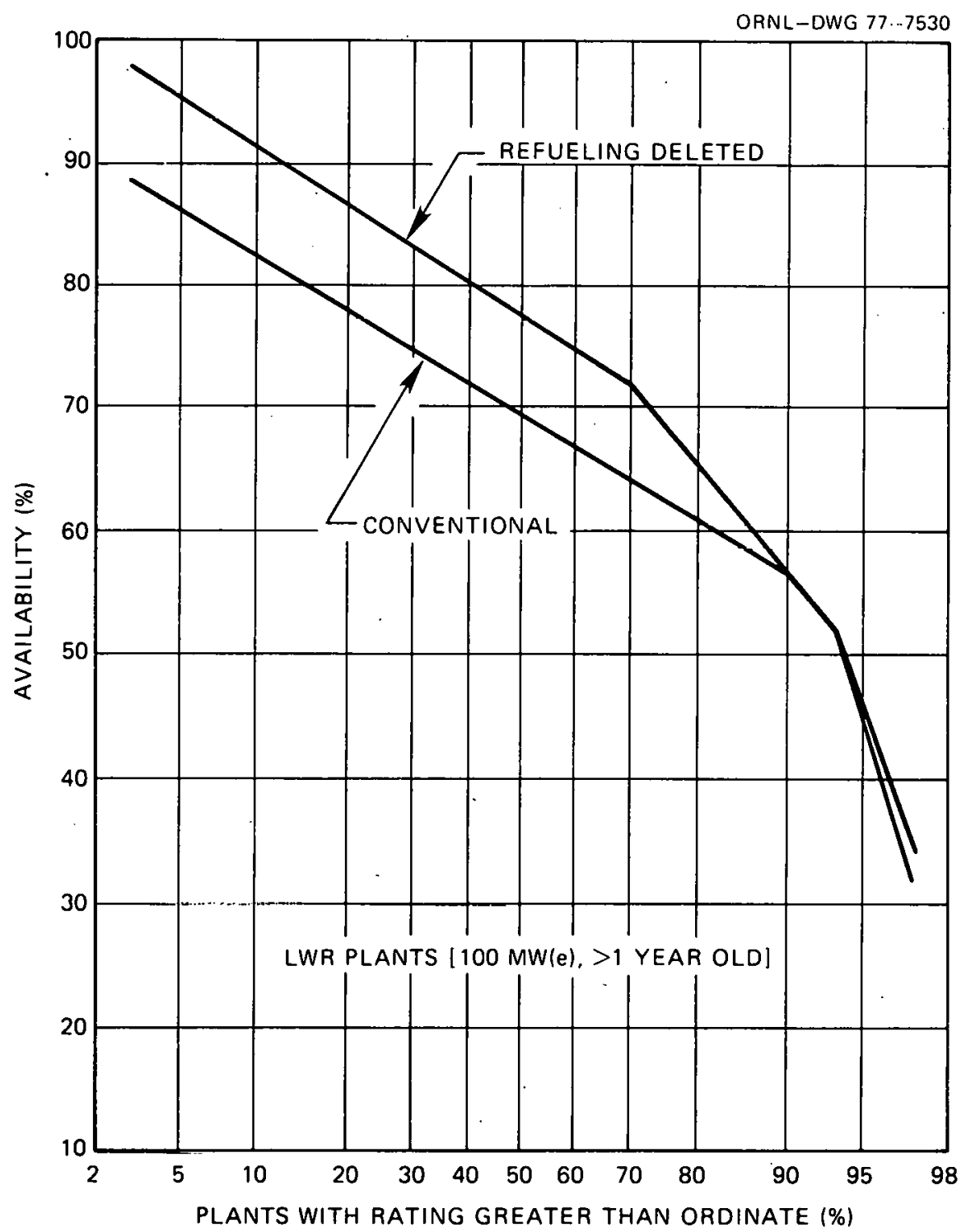

Fig. 3. Plot of cumulative lifetime availability factor illustrating refueling outage impact as of Mar. 1, 1975. From Ref. 7.

That is, operational maturity of a nuclear plant cannot be expected until after the plant has gone through an initial "shakedown" period in which early difficulties are detected and resolved. Another EPRI publication 5 shows that the average capacity factor (defined in Appendix C) for all nuclear plants from the time they were commercially operative is $57 \%$, hut that this value increases with time and experience. 
After the second refueling, the average capacity factor for all plants was $74 \%$, as depicted graphically in Fig. 4.

The average time for reactor refueling, which occurs about every 18 months, was estimated ${ }^{7}$ to be $1736 \mathrm{hr}$. This means that the expected annual refueling time is about $1200 \mathrm{hr}$ for commercial BWRs and PWRs.
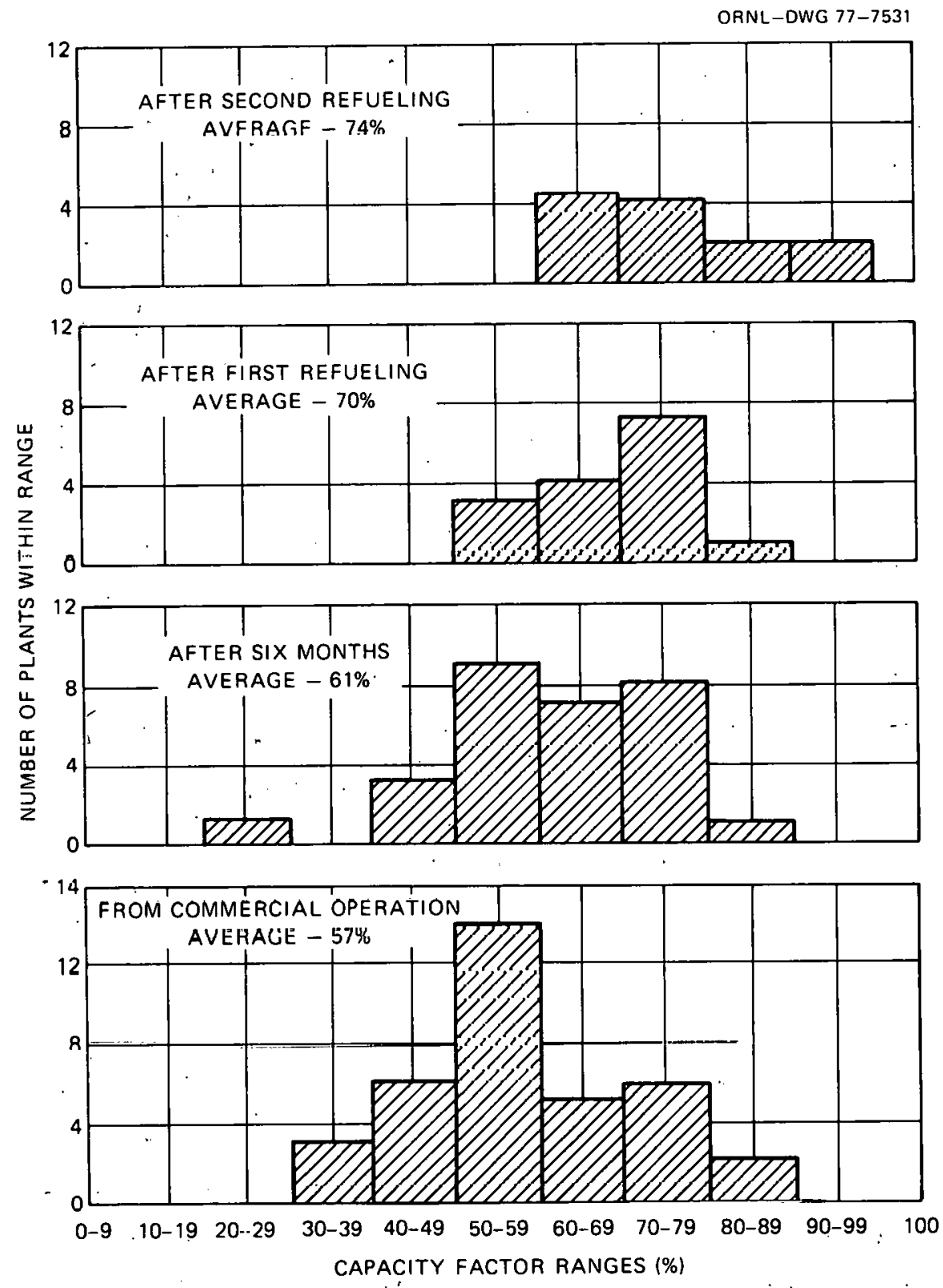

Fig. 4. Capacity factor distributions. From Ref. 5. 
However, the report notes that many current nuclear units were not designed to allow rapid refueling because this capability was not con-

- sidered of major importance at the time. Cumulative data on refueling outages show considerable evidence of a "learning curve" effect, so that it is reasonable to expect refueling times to decrease by 400 to $600 \mathrm{hr} /$ year in the near future. Consequently, a range of refueling times is utilized in some of the illustrative problems presented later.

\subsection{Reactor Reliability vs Unit Size and Age}

Both the NRC and the EEI statistics indicate that reliability, as measured in terms of average forced outage rates and availability factors, decreases as the size of the nuclear unit increases. This apparent phenomenon may be caused by the relatively small number of units comprising the data base and/or the lack of design maturity in the larger units.

In an FEA study, 8 it was reported that reliabilities of older and smaller nuclear units are generally better than those of the newer and larger designs. The relationship between unit size escalation, design maturity, and reliability was also investigated. Figures 5 and 6 , which are taken from the FEA report, show average yearly availability factors (defined in Appendix C) for two classes of nuclear power plants. Figure 5 shows average availability factors vs years of service for the Yankee-Rowe, Indian Point No. 1 , and Dresden No. 1 units, which are in the 175- to 260-MW range. These units were first-of-a-kind power reactors and have been in service for 12 to 14 years. The information is plotted in Fig. 6 for the Humboldt Bay and Big Rock Point units (70 and $80 \mathrm{MW})$, which have been in operation for about 12 years.

For both groups of units, the unit availability shows a general increase over the first 3 to 4 years of operation followed by a gradual decline in more recent years. Figures 5 and 6 also show that the availability after 10 years of service is at least as good as or better than it was in the initial years, with smaller units showing more improvement than the larger units. 


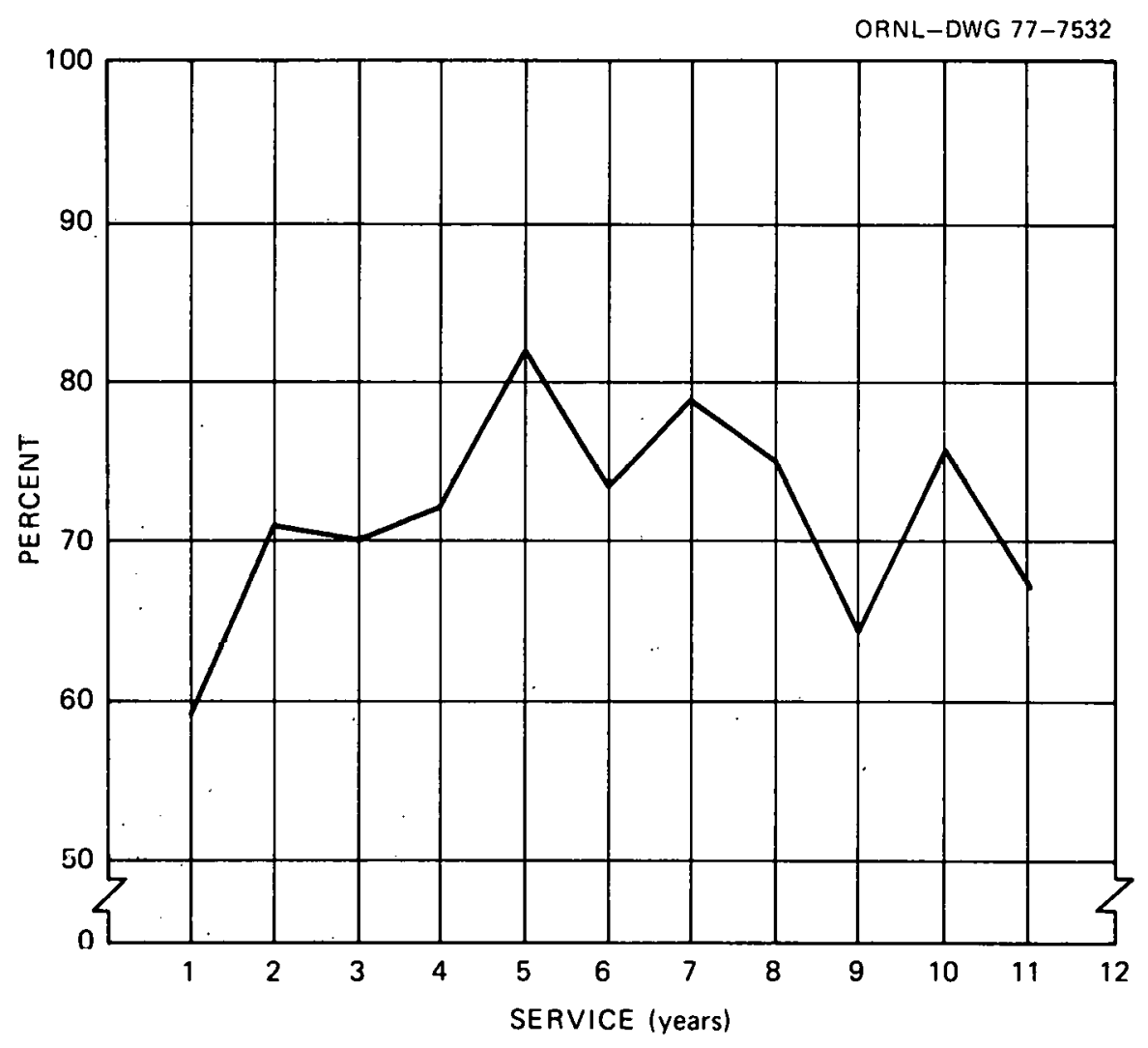

Fig. 5. Average yearly availability factor-Dresden 1, Indian Point 1, and Yankee-Rowe, 1962-1972. From Ref. 8.

Data from the July 1976 issue of the NRC report ${ }^{3}$ were analyzed to gain some insight into recent experience with reliability vs unit size. Results shown in Table 9 indicate that average reactor availability factors and average unit forced outage rates were adversely affected by larger unit sizes. Since only power plants that generated electricity during June were considered, it is realized that this sample of one month's data does not produce statistically significant results but rather indicates a trend. Table 9 is presented to further prove the validity of the FEA claims.

Nuclear data reported in this and the previous two subsections are utilized in Section 4 in evaluating the overall reliabilities of multipleunit nuclear and fossil-fired steam supply. s.ystems. 


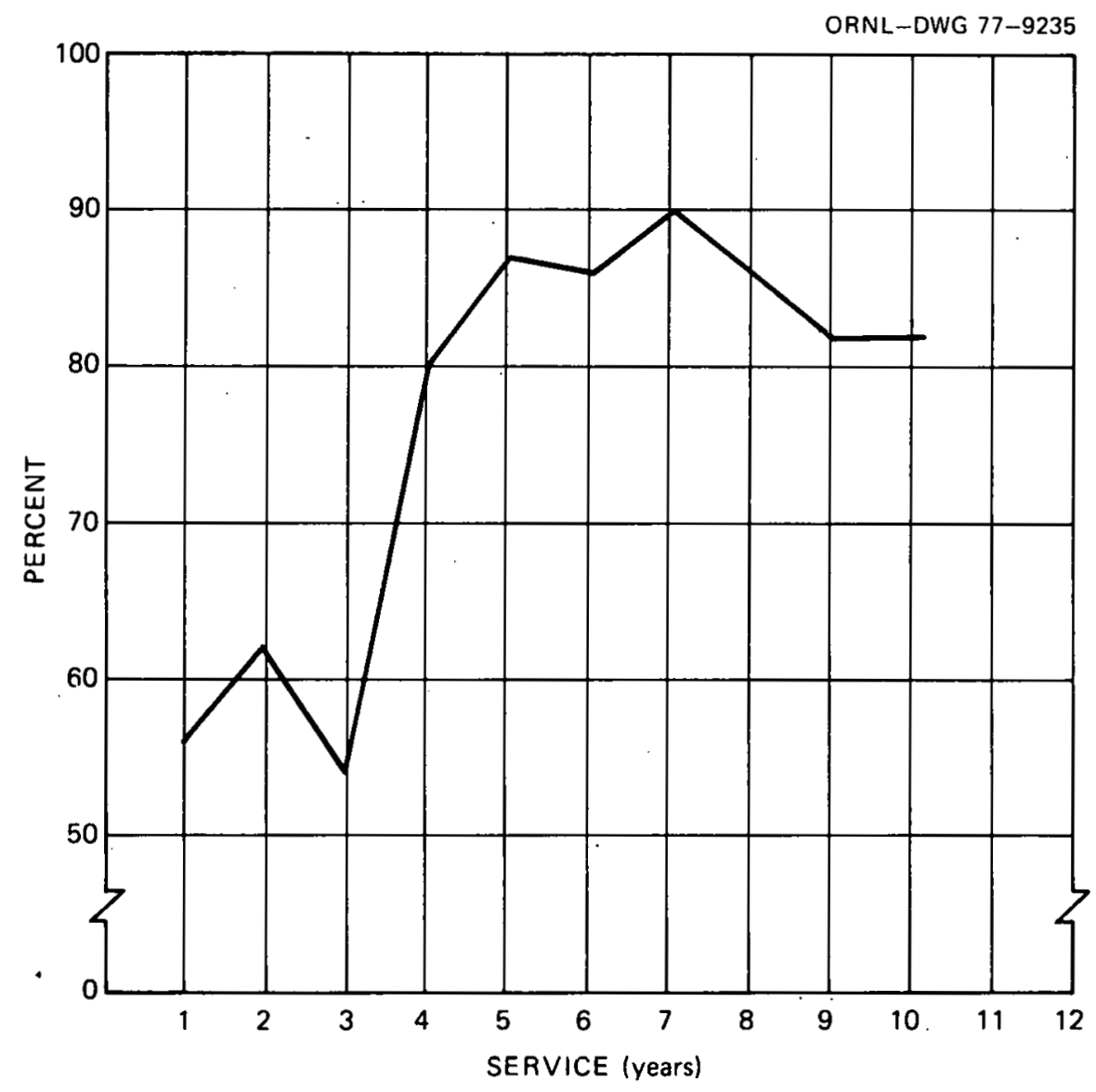

Fig. 6. Average availability factor vs years of service - Humboldt Bay and Big Rock Point, 1963-1972. From Ref. 8.

'lable 9. Unit size vs reactor availability

factor and unit forced outage rate for

plants operating in June 1976

\begin{tabular}{ccc}
\hline Unit size & $\begin{array}{c}\text { Average reactor } \\
\text { availability factor }(\%)\end{array}$ & $\begin{array}{c}\text { Average unit } \\
\text { forced outage rate (\%) }\end{array}$ \\
\hline $\begin{array}{c}<75 \mathrm{MW}(\mathrm{e}) \\
(1 \mathrm{plant})\end{array}$ & 100.0 & 0.0 \\
$\begin{array}{c}175-499 \mathrm{MW}(\mathrm{e}) \\
(10 \mathrm{plants})\end{array}$ & 96.5 & 7.5 \\
500 MW(e) and above & 86.9 & 7.6 \\
\hline
\end{tabular}




\subsection{Reliability of Fossi-Fired Boilers}

Reliability data for fossil-fired boilers are published yearly by EEI. 6 Although these data are gathered from electric utilities on a voluntary basis, they are believed to comprise a representative sample of boiler manufacturers and the various sized units in common use. Definition of terms follows EEI practice as given in Appendix C. Generally speaking, data bases for the nuclear plants are more comprehensive and current than those from fossil plants.

Table 10 shows operating availability, forced outage rate, and mean time between forced outages for various sized boilers. As indicated in the table, total unit forced outage rates are considerably higher for the large boilers. The rates for boilers of $600 \mathrm{MW}$ and above exceed $9 \%$, and the availability of these systems is approximately $82 \%$. For units of the same size, these statistics are comparable to the Nuclear steam supply (NSS) portion of electrical power stations.

Table 10. Availability and forced outage rates of tossil-tired boilers (1965-1974)

\begin{tabular}{lccc}
\hline $\begin{array}{c}\text { Boiler size } \\
{[\mathrm{MW}(\mathrm{t})]}\end{array}$ & $\begin{array}{c}\text { Operating } \\
\text { availability }(\%)\end{array}$ & $\begin{array}{c}\text { Forced outage } \\
\text { rate (\%) }\end{array}$ & $\begin{array}{c}\text { Mean time between } \\
\text { forced outages (hr) }\end{array}$ \\
\hline $60-89$ & 93.3 & 1.2 & 3664 \\
$90-129$ & 90.9 & 2.4 & 2064 \\
$1.30-1.99$ & 91.0 & 2.5 & 1748 \\
$200-389$ & 88.2 & 3.6 & 1563 \\
390.599 & 84.6 & 5.6 & 1155 \\
600 and above & 82.2 & 9.3 & 793 \\
\hline
\end{tabular}

In a companion study, ${ }^{2}$ it wae found that most industrial boilers used to produce process steam have a capacity of $31.5 \mathrm{~kg} / \mathrm{s}(250,000 \mathrm{lb} /$ $\mathrm{hr}$ of steam) or less. This roughly corresponds to the 60- to 89-MW category in Table 10. The figures for this size boiler correspond 
reasonably well with average equipment (boiler) related outages reported by the chemical and petroleum refining industries in the study cited above.

Selected reliability measures ${ }^{6}$ for $600-\mathrm{MW}$ and larger fossil-fired units are shown in Table 11. These data were gathered from electric utilities that use boilers to meet a highly variable demand. Boilers used to produce industrial process steam are not subject to widely fluctuating demands and may have higher operating availabilities than their counterparts in electrical utilities. For purposes of demonstrating the methodology, however, it is assumed that the EEI data are representative of industrial boiler experience. Therefore, the data of Tables 10 and 11 are utilized in the illustrative problems.

Table 11. Availability and forced outage rates of major components in fossil-fired units $600 \mathrm{MW}$ and larger ${ }^{\mathrm{a}}$

\begin{tabular}{lccc}
\hline Component & $\begin{array}{c}\text { Operating } \\
\text { availability }(\%)\end{array}$ & $\begin{array}{c}\text { Forced outage } \\
\text { rate (\%) }\end{array}$ & $\begin{array}{c}\text { Mean time between } \\
\text { forced outages (hr) }\end{array}$ \\
\hline Boiler & 82.2 & 9.3 & 793 \\
Turbine & 88.4 & 3.4 & 3,341 \\
Condenser & 96.3 & 0.2 & 19,208 \\
Generator & 91.4 & 3.5 & 8,698 \\
Other & 95.0 & 1.3 & 2,791 \\
Totai untt & 73.3 & 15.8 & 481 \\
\hline
\end{tabular}

Data base consists of 81 units with combined unit years equal to 285 . 


\section{ANALYTICAL PROCEDURES}

Two methods have been used in this study to estimate the reliability of steam supply systems. The first is a Monte Carlo method, in which a series of operating histories is calculated and the reliability of the system determined by analyzing these histories. The second is a probability calculation similar to that used in the electric power industry to calculate loss of load probability (LOLP) and loss of energy probability (LOEP). The first method can be used for systems of coneidcrable complexity, while the second can become very cumbersome for complicated systems. These methods are described below.

It is worth noting that the reliability requirements for combined nuclear and fossil-fired fuel steam supplies for industry differ with application and differ from those in the electric power industry. In the electric power industry, one commonly used reliability criterion is "it is not acceptahle to be unable to meet energy demands more than one day in ten years." Although voltage reductions are common, they are not considered in determining the generating capacity needed to meet the reliability requirement. This reflects the fart that although oome customers are far better able to cut back on power use than others, it is often impossible or else snrially or politically iumpraccirabie to get tlieul to do so when necessary. Hence, the electric utilities must have a large reserve generating caparity (15 to $20 \%$ above peak load is a common criterion) with its attendant capital cost. In some industries (e.g., nylon mallufacturé), a steam failure is so disruptive that a reliability crlterion as strict as that of the electric power industry is justified. In other iluduslries, à steam failure results in momentary loss of production without major other effects, and a lower reliabilily is acceptable. In many induetrica, part of a plant may be shut down with little penalty to maintaining operations in another more essential part. Typically, an electric utility also has a high reliability because its generating capacity is spread among many independent cources, either in its own system or in the regional power reliability council of which it is a member. In contrast, much industrial steam will come from a small number of boilers with no interconnections to external power sources. The 
reliability requirements for each industrial installation should be established on an individual basis, taking into account the impact on the installation of a forced outtage of steam supply; some installations can easily curtail operations while others incur a heavy economic penalty if they are forced to shut down.

Another factor to consider is the use of the steam capacity in excess of that required to generate process steam. One policy is to place boilers not needed to meet current steam requirements on hot (or cold) standby, while another is to use the excess steam to generate by-product electricity. A recent survey shows that most plants with large steam requirements also have large electric power requirements. 9 Many of these already have their own fossil-fueled electricity generating plants. In general, these operate on top of the process steam cycle; that is, turbines for generating electricity use high-temperature steam and exhaust low-temperature steam for process use, resulting in a very low unit electricity cost. In general, it may be most economical for most plants to use their excess steam capacity to generate electricity, first to displace that which they purchase from an electric utility and then to sell (if a buyer can be found). The legal, economic, and environmental issues associated with this mode of operation have been studied elsewhere. 10

In the Monte Carlo calculation, one can assume that excess steam is used to generate electricity or that excess boilers are placed on standby. If one or more units are off line because of forced and/or scheduled outages, generation of electricity is initially curtailed. When the combined outage is severe enough, steam production will drop below requirements; resulting in an unreliable steam-supply system. In the case where the system is characterized as unreliable, rules for determining how the steam loss affects production processes can be specified by the user of the computer program developed in the present study. This option is included because large reductions in steam supply will affect industries in many different ways. In addition, if the user has more steam generators operable than he chooses to include in a particular alternative, the mix of units can be varied and evaluated as separate alternatives. With this approach, the effect of keeping high-cost units on "permanent standby". can be evaluated. Such units would be called upon in emergency situations only. 
It should be emphasized that these procedures can be used to determine the reliability of systems having various combinations of nuclear and fossil-fired steam generators if the outage rate of the individual generators is known beforehand. These procedures do not include factors that determine individual reactor or fossil-fired boiler outage characteristics - these values are assumed to be given quantitites for present purposes.

The accuracy of the calculated results will depend on how well the input data are known and on the calculational techniques employed. For the probabilistic method, techniques are available to express the sland= ard deviation of the results in terms of the standard deviations of the input data. For the Monte Carlo calculations, the input data can be represented directly $I_{11}$ Leiús of an appropriatc dietribution function. (In the sample problems, uniform dislribuliuins were assumed for cimplicity.) The accuracy of the results then improves as the number of case histories is increased. A detailed discussion of these aspects is beyond the scope of the present report. 11

\subsection{Monte Carlo Computer Program}

The purpose of this computer program is to estimate the reliability of an industrial steam supply system consisting of mulliple sources. The operating characteristics (outage frequency and duration, time required to place the unit on line, etc.) of Individual power sources must be known so that the various operating modes of the system can be defined.

A flow diagram for the Monte Carlo calculation of example 3 is shown in Fig. 7. A corresponding diagram for example 2 would differ only in minor delails.

A computer is used to keep track of a simulated period of operation (normally 12 to 18 months) of the plant, including hourly steam generating capacity, hourly steam load, and hourly steam used to make electricity. The computer tallies the hours when the load is not met, the steam from each boiler, the electricity generated, and similar quantities of interest. The computer program uses appropriate input data and random numbers to determine the occurrence of forced outages, the lengths of repair periods, 


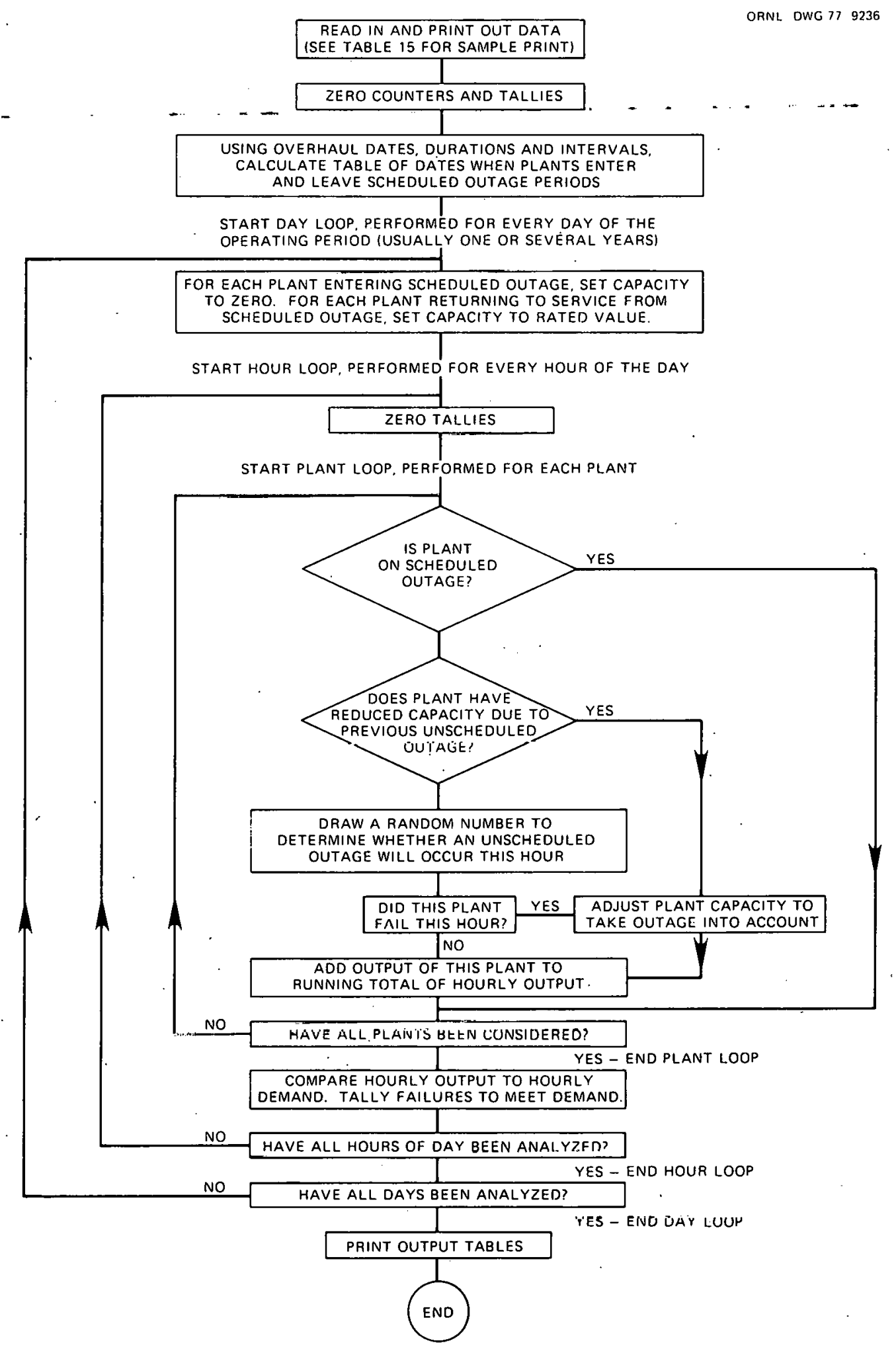

Fig. 7. Flow diagram for the Monte Carlo calculation of example 3. 
and other random variables. Different computer runs will give different results because different sets of random numbers are used from one simulation to the next. To determine system reliability, one makes a series of such calculations and keeps a running average of the results. When this average seems to have stabilized to a narrow range of values, it is a reasonable estimate of the quantity desired. An error estimate is obtained by determining the mean and standard deviation of the results and applying statistical theory assuming a normal distribution of simulation outcomes. The "33 years of operating experience" reported in a later example problem represents the results of 33 independent calculations for one year each, with a different set of random numbers for each calculation.

The Monte Carlo method makes it possible to incorporate into the calculation a number of assumptions that are dependent un the individual installation. In addition to the assumption mentioned above - that excess steam is used to generate electricity - other assumptions concern power load requirements and boiler characteristics.

It is assumed that in event of a steam supply failure, each industrial plant will modify its steam consumption as a function of time and amount of steam available. The function defining the steam usage after failure is read into the computer program as input data.

A. number of operating conditions, represented by input data, are required for each boiler. The first of these is rated steam gcnerating capacity, usually, stated in millions of pounds per hour. Next are scheduled time between overhauls and scheduled duration of overhaul. Extensions of the scheduled overhaul period can be provided by letting this variable take on random values in accordance with a prescribed distribution function. The mean time between failures and mean time for repairs are additional required datà. The repalı llue uidy be trcatcd oo a randou variable, with the spectfled mean repair time and a variation from the mean which is treated as a random variable. In addition, the timea rcquired for the steam output to coast down to zero after a failure or to build up rated power after repairs are completed may be used in the calculation.

Although not included in the illustrative calculation that will be described later, additional refinements (such as major. and minor overhaul 
periods at different intervals and of different durations and a mixture of partial and complete outages) could be made.

It is assumed that any company contemplating the acquisition of a nuclear reactor to supply process heat would have access to a computer facility. It would develop an appropriate computer simulation of its system and calculate its expected performance before making as large a financial commitment as the purchase of a reactor. The examples described later are intended to be illustrative only. They are less specialized than those a company might employ for analyzing a specific application. Other cost-related factors would, of course, also be taken into consideration.

In such a simulation the function of the computer is to keep a running record of the status of each part of the system and to accumulate the totals for such quantities of interest as energy supplied and hours of operation. No complex calculations are required. The ability of the computer to generate random numbers provides the means for controlling the occurrence of outages in the simulation.

A printout of the input data example problem 3 illustrates the type and amount of data required (see Table 15 in Section 4.3).

\subsection{Probabilistic Method}

This method can be used to generate various measures of a system's reliability for given inputs of certain reactor and boiler operating characteristics. It does not provide for any details of load adjustment, capacity coastdown, or delay in power recovery when an outage occurs.

For each steam supply (reactor, boiler, etc.) a plot of the probability $P$ that the output will exceed the amount. $x$ will resemble the sketch below:

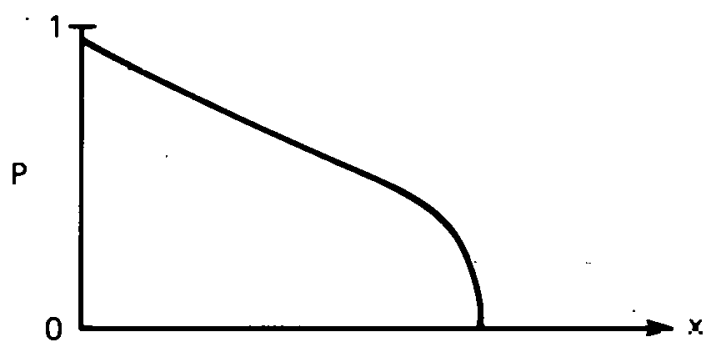


If the unit is assumed to have a constant availability $R$ (as defined in Appendix $C$ ) and capacity $C$, the sketch will resemble:

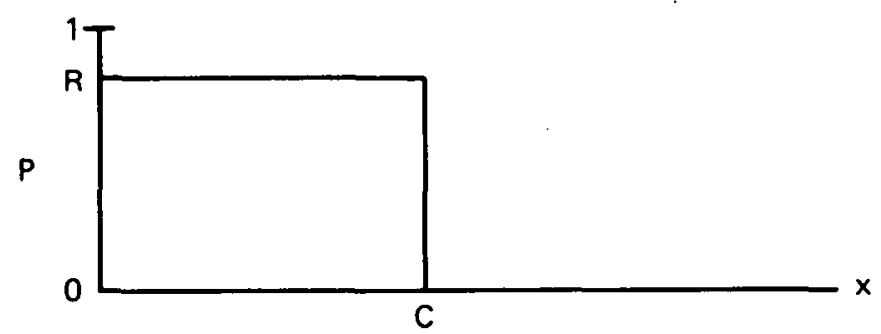

Here $P(x)$ is the probability that the unit's steam supply is at least $x$. For two units having availabilities $R_{1}$ and $R_{2}$ and capacities $C_{1}$ and $C_{2}$. (with $\mathrm{C}_{1}>\mathrm{C}_{2}$ ), the sketch will be:

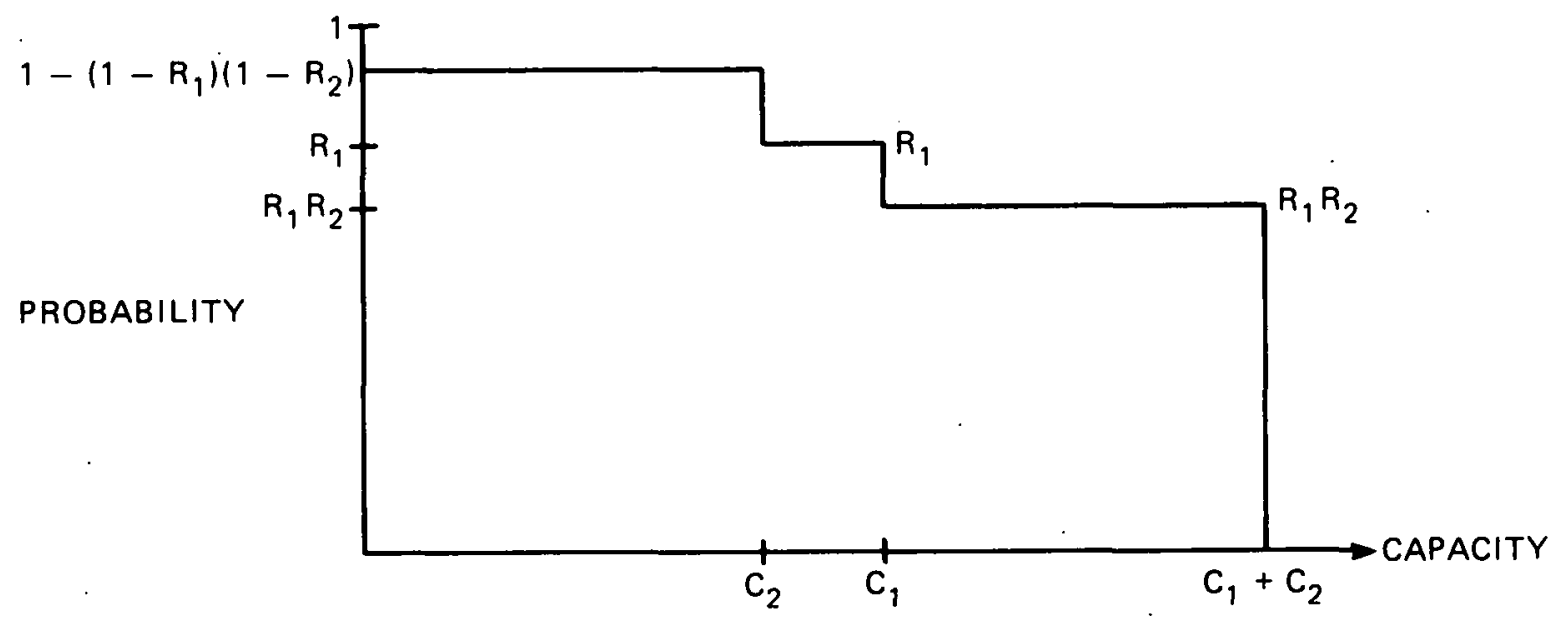

As further units are added, the sketch takes on the form of a staircase:

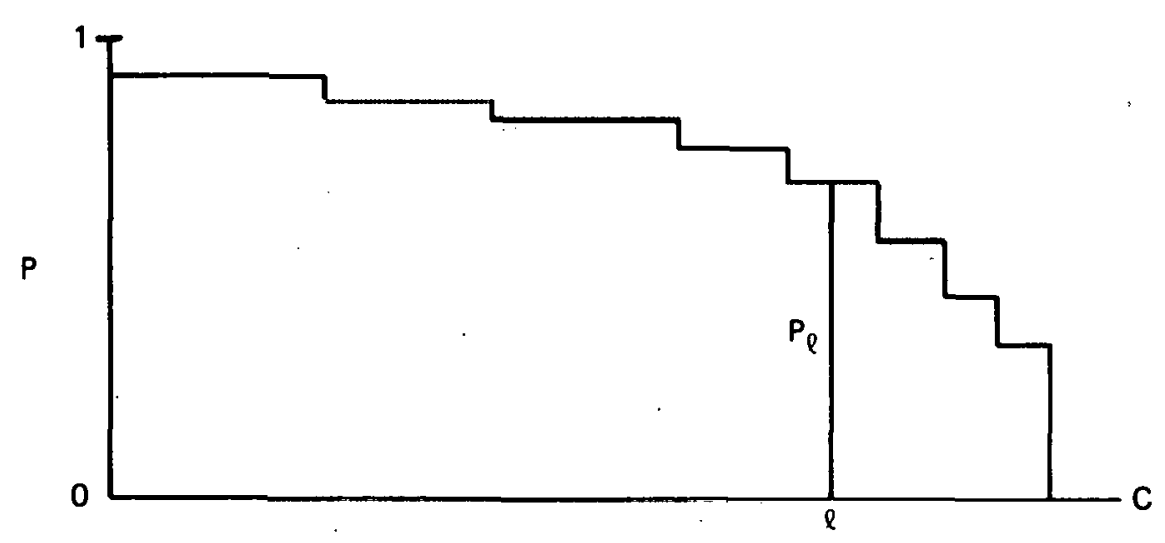


If the system load is $\ell$, then in the above diagram the probability that the system capacity will be greater than or equal to $\ell$ is $P_{\ell}$, which will be the aggregate availability of this system.

In terms of the sketches above, the algorithm for adding a unit of capacity $C$ and availability $R$ to the system is (1) multiply each ordinate on the original curve by $\mathrm{R}$ and shift it $\mathrm{C}$ units to the right, and then (2) calculate $(1-R)$ times each ordinate on the original curve, and (3) add the results of (1) and (2). The results will be the probability-vs-capacity curve for the augmented system.

In performing step 1 , assume $P=1$ for all negative values of capaclty. This subject is discussed in more detail in Ref. 12.

In example case 2 below, there are five equal boilers. If the capacity of each is $C$ and the availability $R$, the diagram becomes

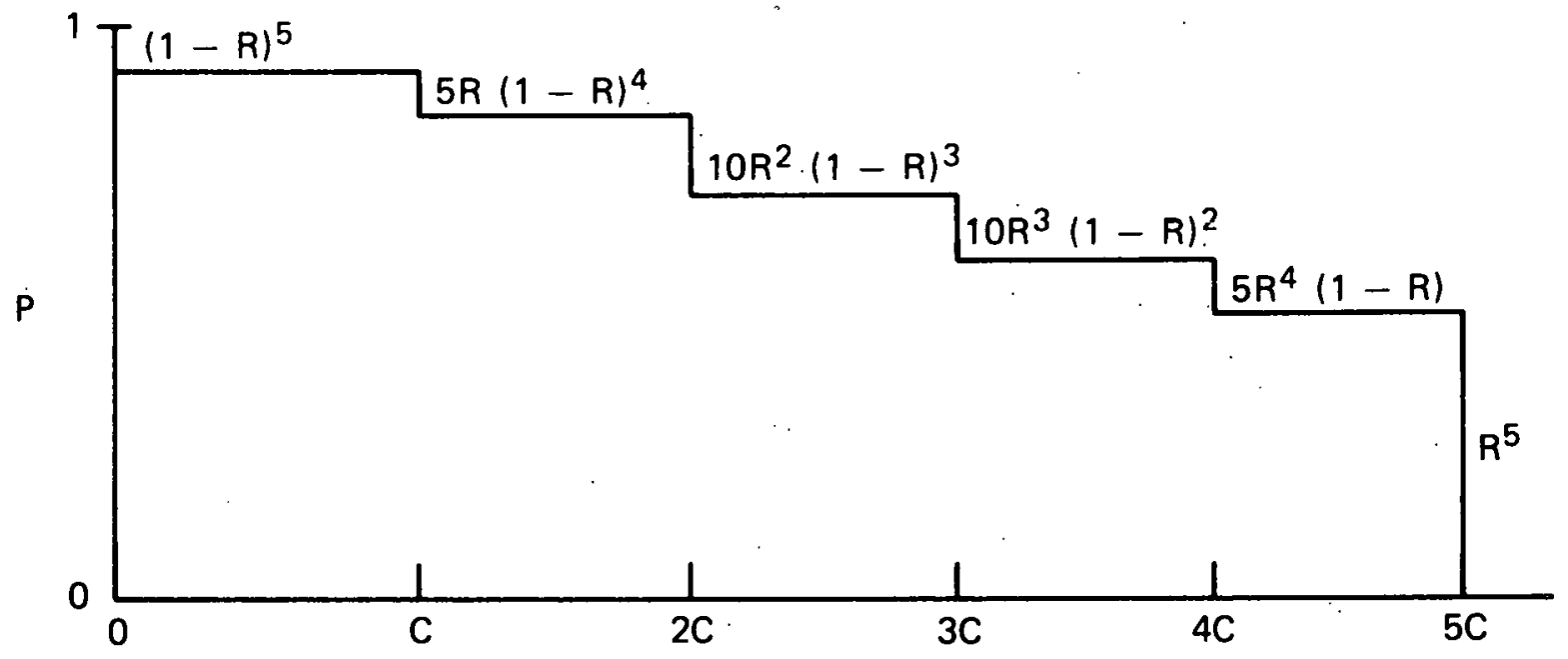

where the heights of each step in the "staircase" will be recognized as the terms of the binomial theorem expansion of $([1-R]+R)^{5}$.

Thus, for example, the probability that the total capacity exceeds $C$ is 1 minus the sum of the first two terms:

$$
1-(1-R)^{5}-5 R(1-R)^{4}
$$

The application of probabilistic methods of analysis varies greatly with the complexity of the system being studied and the degree of detail in the analysis. In illustrative example 1 of Section 4.1, all that is 
required to determine overall system availability is the straightforward use of the rules for determining probabilities of statistically independent events. In illustrative example 2 (Section 4.2), either a Monte Carlo or a probabilistic method using hand calculations might be used. I11.11strative example 3 (Section 4.3) requires so much computation that a digital computer would be needed. If the system is relatively homogeneous, such that any boiler can supply any load, it can be analyzed by one of the computer programs used for scheduling electric power generation capacity, such as ORSIM. ${ }^{3}$ Such a program will calculate the expected power generation from each unit, the optimal maintenance schedule, the system availability, and vilier prupeities. By further manipulations, described in Ref. 14, the method can be used to estimate the probable load to be furnished by each generator (or boiler). However, the input data required are numerous. If the system is not homogeneous and contains units operating at various different temperatures and pressures so that only certain comblnations of units can be used together, the probability analysis is likely to become so complicated as to be impractical, and a Monte Carlo analysis will be preferable. 


\section{APPLICATION OF THE METHODOLOGY}

The reliability characterislics used to illustratc the methodology are based on EEI and NRC data cited previously, as well as on other sources. The characteristics are intended to be representative of a range of equipment that might be used to supply industrial steam needs; no attempt was made to model a specific industrial complex.

\subsection{Example Problem 1}

This example illustrates the use of the probabilistic method to determine the availability of a power supply system that consists of two $3750-\mathrm{MW}(\mathrm{t})$ nuclear reactors that supp1y $756 \mathrm{~kg} / \mathrm{s}\left(6 \times 10^{6} \mathrm{lb} / \mathrm{hr}\right)$ of steam for industrial uses and up to $1850 \mathrm{MW}(\mathrm{e})$ of electric power to the local power grid. The definition of availability as used in example 1 is given in Appendix C. Either reactor can supply heat to a reboiler, which produces the steam, and either or both reactors can supply steam to a turbine generator. The system. is similar to that described in section A-3 of Appendix A; the configuration is outlined in Fig. 8. Because there are only a few system components to be considered, this example can be calculated by hand. Let the probability that reactor 1 is operational be $\mathrm{P}_{1}$, the probability that reactor 2 is operational be $\mathrm{P}_{2}$, and the probability that the reboiler is operational be $P_{R}$. The plus symbol means that the indicated component is operable, and the minus symbol means that the compunul is not operablc. One can then tabulate the states of the system and their probabilities as follows:

\begin{tabular}{|c|c|c|c|c|}
\hline State & Reactor 1 & Reactor 2 & $\underline{\text { Reboiler }}$ & \\
\hline A & + & + & + & $\mathrm{P}_{1} \mathrm{P}_{2} \mathrm{P}_{\mathrm{R}}$ \\
\hline B. & + & - & + & $\mathrm{P}_{1}\left(1-\mathrm{P}_{2}\right) \mathrm{P}_{\mathrm{R}}$ \\
\hline $\mathrm{C}$ & + & + & - & $\mathrm{P}_{1} \mathrm{P}_{2}\left(1-\mathrm{P}_{\mathrm{R}}\right)$ \\
\hline $\mathrm{D}$ & + & - & - & $P_{1}\left(1-P_{2}\right)\left(1-P_{R}\right)$ \\
\hline $\mathrm{E}$ & - & + & + & $\left(1-P_{1}\right) P_{2} P_{R}$ \\
\hline $\mathrm{F}$ & - & - & + & $\left(1-P_{1}\right)\left(1-P_{2}\right) P_{R}$ \\
\hline G & - & + & - & $\left(1-P_{1}\right) P_{2}\left(1-P_{R}\right)$ \\
\hline $\mathrm{H}$ & - & - & - & $\left(1-P_{1}\right)\left(1-\bar{P}_{2}\right)\left(1-P_{R}\right)$ \\
\hline
\end{tabular}




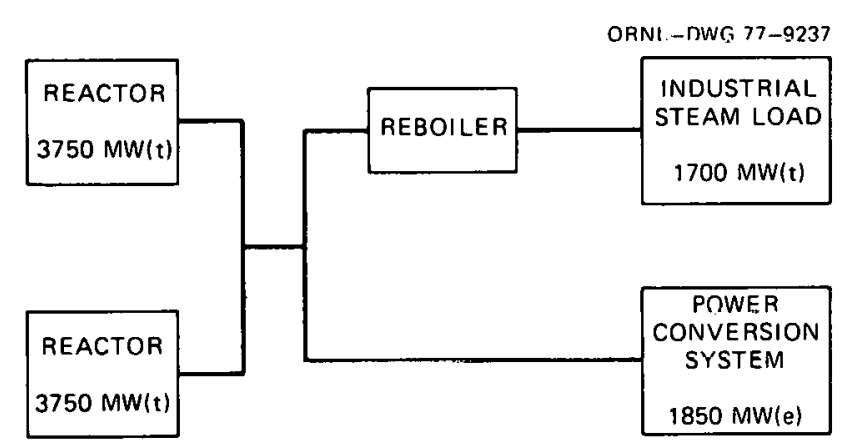

EXAMPLE 1

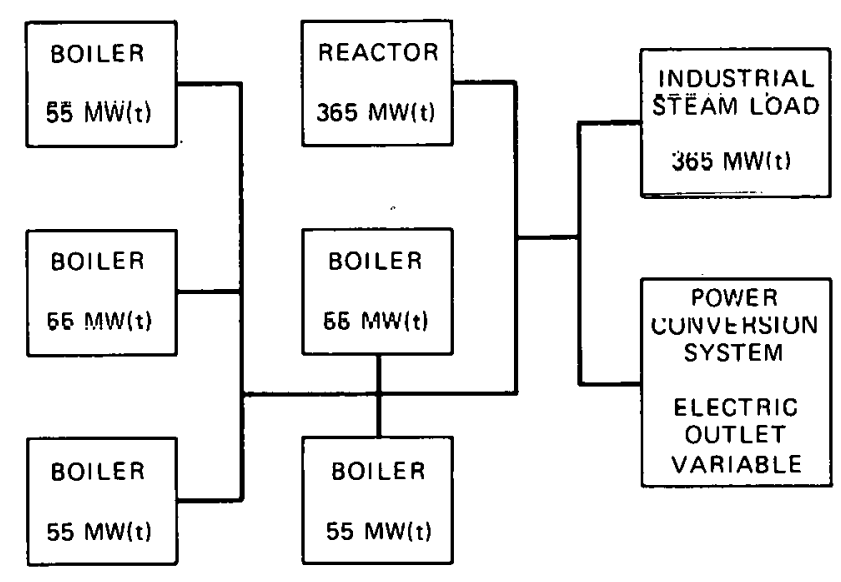

EXAMPLE 2

Fig. 8. Configurations for examples 1 and 2 .

The probability of having industrial steam service when neither reactor is down for scheduled maintenance is the sum of the probabilities for. states $A, B$, and $E$ :

$$
\left(\mathrm{P}_{1}+\mathrm{P}_{2}-\mathrm{P}_{1} \mathrm{P}_{2}\right) \mathrm{P}_{\mathrm{R}}
$$

When reactor 1 is on scheduled outage, the probability of having steam is $\mathrm{P}_{2} \mathrm{P}_{R}$; when reactor 2 is on scheduled outage, this probability is $\mathrm{P}_{1} \mathrm{P}_{\mathrm{R}}$.

A numerical example of the above relations can be given using representative reliability indices. The reactor availability was taken to be in the range 0.80 to 0.90 , which includes the value of 0.866 derived from line 9 of Table 3 . The reboiler availability was assumed to range 
from 0.94 to 0.98 , which straddles the average steam generator availability of 0.954 implied in Fig. 2. For these parameters, the availability of the steam supply ranges from 0.902 to 0.970 when neither reactor is scheduled for overhaul and from 0.752 to 0.882 when a reactor is being overhauled.

The annual average availability is obtained by combining these results with proper time weighting for the, period, giving an annual average availability for the system that ranges from 0.86 to 0.95 , as shown in Table 12. The improvement in system performance achievable with the addition of one conventional fossil-fired 1700-MW( $t$ ) backup boiler that is assumed to have an availability of 0.85 is also shown in the table. Thus,

Table 12. Steam system availability calculated for example 1

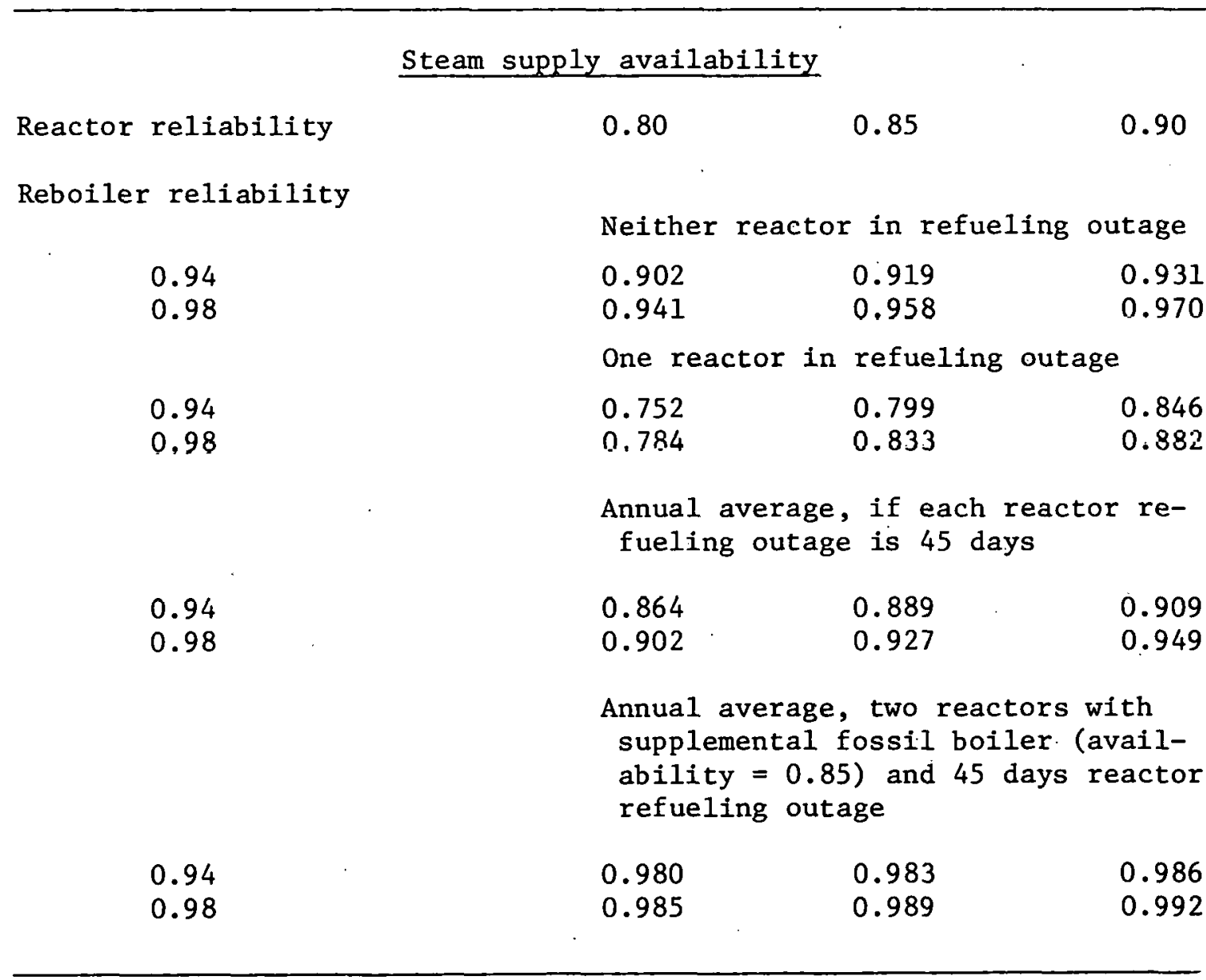


the average annual availability of the nuclear steam supply system supplemented by one backup boiler ranges from 0.98 to 0.99 . The system availability was obtained from the expression

$$
R_{S}=1-\left(1-R_{c}\right)\left(1-R_{n}\right)
$$

where $R_{n}$ is the availability obtained previously for the system powered by two reactors only, $R_{C}$ is the availability of the conventional boiler, and $\mathrm{R}_{\mathrm{S}}$ is the availability of the steam supply system that includes two reactors and one fossil-fired boiler:

\subsection{Example Problem 2}

This example illustrates the use of the Monte Carlo method to determine the reliability of an industrial puwes supply system that consists of one PWR rated at $365 \mathrm{MW}(t)$ and five oil- or gas-fired boilers rated at 55 MW $(t)$ each (reliability as used here was defined earlier). The reactor provides steam to generate electricity and, more importantly, to provide heat for an industrial process. The process requires that its working material be kept molten by application of heat; if this materlal should solidify throughout the system, resumption of system operation would be very expensive. At least $20 \%$ of the rated reactor output [i.e., $73 \mathrm{MW}(\mathrm{t})$ ] is required to keep the material molten throughout the system, with productive output reduced to zero. Therefore, it is very important that a steaming capacity of at least $73 \mathrm{MW}(t)$ be maintained. It is assumed that when the reactor is out of service, either duc to scheduled or forced outage, all avalluble boilers will bo used and the plant will operate at partial outpue. If the leaclur is opcrating at full capar1tyr; the plant will he able to operate at full capacity, and two or three boilers will be kept on standby with the uthitss tither cold or in ccheduled maintenance. Whether the two boilers on standby will be hot or cold depends on the rate at which the material cools in the absence of a heat supply and the time required to bring the boilers on line. That is, if the material remains liquid for a period equal to or greater than that required to bring the standby boilers up to power, the boilers may be 
kept on cold standby; otherwise they must be kept at least partly heated, possibly by circulating some steam through their steam drums. Since at least two boilers are required to operate when the reactor is down, it would seem necessary to have three boilers ready for quick firing, unless experience shows that the boilers start very reliably.

From this discussion, it will be apparent that calculated failure rates will be exceedingly sensitive to the assumptions regarding unit performance. In the second illustrative example the following assumptions were made:

Plant type

Capacity, MW(t)

Mean time between failures, days

Mean repair time, days

Mean time between overhauls, days

Mean overhaul time, days

Coastdown power time, $\mathrm{hr}$

Buildup power time, hr $\underline{\text { PWR }}$

365

$40,70,100$

3.4

360

20,30

1,4

6
Boiler

55 each

150

2

360

30

3

5

The data for each power source include mean time between failures, mean time required for repair, mean time between scheduled maintenance, and mean time for scheduled maintenance. The PWR parameters used in this sample problem span a range that is pertinent to small reactor applications. The mean time between failure ranges from 40 to 100 days. The value of 82 days for mean time between forced outages (Table 8, line 1) for a ten-year operating history of nuclear units of all sizes falls within the selected span. The mean repair time of 3.4 days was taken from Table 7. Scheduled maintenance is characterized by a mean time between overhauls of 360 days and refueling outage times of 20 and 30 days. Some improvement over reactor experience obtained to date (Table 7) was assumed here to account for the plant improvements achlevable in a standardized small reactor. For the fossil-fired boilers, a mean time of 150 days between forced outages was taken from line 1 of Table 10 . A mean time of 2 days to complete repairs is consistent with the forced outage rate of Table 10. The scheduled overhaul time for the fossil 
units is consistent with the availability data of Table 10. Startup of each steam source was approximated by assuming a linear increase in steam flow from zero to $100 \%$ of full power during the indicated "time required to build up power." Shutdowns were treated similarly.

The repair times, overhaul times, and times of failure are random variables whose values are determined by use of a random number generator. The repair times are uniformly distributed over a representative range, namely from 50 to $150 \%$ of the values tabulated above. The overhaul times are uniformly distributed between 100 and $130 \%$ of the values tabulated above. The mean time between failures is converted to an hourly probability of forced outage. For each operational unit, a random number (from a population uniformly distributed from 0 to 1) is generated every hour. If this is less than or equal to the hourly probability of forced outage, a failure is assumed to have occurred; otherwise, the unit rnntinues in scheduled operation.

As shown by Tables 13 and 14, several different values of mean time between failures and of overhaul times were assumed and results determined for each. It is hoped that the results will give a feel for the level of system reliability to be expected for a reasonable range of reliability inputs.

Two modes of operation were investigated: (1) all units operate when not on scheduled maintenance or forced outage and any power available above $365 \mathrm{MW}(t)$ is used to generate electricity for sale to the local power company; (2) when the reactor is operating, all boilers not scheduled for overhaul or undergoing repairs are kept on cold standby. When results from Tables 13 and 14 are compared, it will be noted that the greater numbers of forced outages in mode 1 represent fossilfired boiler outages and that the difference in the values of annual average MW( $t)$ available represents the amount of thermal energy that could be converted to and sold as electric energy. The average $M W(t)$ available for sale as electricity is shown in Table 13.

If the probability method is applied to this example, the operating availability of each boiler - assuming no two are deliberately scheduled 
Table 13. Results for example 2 with 33 years of plant operation in mode 1

\begin{tabular}{|c|c|c|c|c|c|c|}
\hline $\begin{array}{l}\text { Mean time between reactor } \\
\text { failures, days }\end{array}$ & 40 & 40 & 70 & 70 & 100 & 100 \\
\hline $\begin{array}{l}\text { Reactor mean overhaul time, } \\
\text { days }\end{array}$ & 20 & 30 & 20 & 30 & 20 & 30 \\
\hline $\begin{array}{l}\text { Hours per year when outdut } \\
<73 \mathrm{MW}(\mathrm{t})\end{array}$ & 0 & 0 & 0 & 0 & 0 & 0 \\
\hline $\begin{array}{l}\text { Annual average number of } \\
\text { forced outages }\end{array}$ & $19.6 \pm 4.5^{a}$ & $19.9 \pm 3.7$ & $16.7 \pm 4.9$ & $16.6 \pm 4.5$ & $15.2 \pm 4.6$ & $15.3 \pm 4.6$ \\
\hline $\begin{array}{l}\text { Annual average number of } \\
\text { reactor forced outages }\end{array}$ & $7.8 \pm 2.6$ & $8.2 \pm 2.3$ & $4.5 \pm 2.1$ & $4.8 \pm 2.0$ & $3.7 \pm 1.7$ & $3.3 \pm 1.4$ \\
\hline $\begin{array}{l}\text { Arnual average } \mathrm{MW}(\mathrm{t}) \\
\text { available }\end{array}$ & $562.6 \pm 8.3$ & $550.7 \pm 8.4$ & $573.4 \pm 8.0$ & $560.0 \pm 7.4$ & $576.0 \pm 5.7$ & $566.2 \pm 5.4$ \\
\hline $\begin{array}{l}\text { Annual average } \mathrm{MW}(\mathrm{t}) \\
\text { on outage }\end{array}$ & $29.1 \doteqdot 8.2$ & $29.7 \pm 7.1$ & $18.0 \pm 7.5$ & $19.4 \pm 6.8$ & $15.2 \pm 5.9$ & $13.9 \pm 5.1$ \\
\hline $\begin{array}{l}\text { Annual average MW(t) for } \\
\text { sale as electricity }\end{array}$ & 185.1 & 176.7 & 172.8 & 172.0 & 174.3 & 166.3 \\
\hline $\begin{array}{l}\text { Reactor hours out, annual } \\
\text { average }\end{array}$ & $646.4 \pm 2.6$ & $660.4 \pm 179.8$ & $362.7 \pm 177.3$ & $400.9 \pm 164.6$ & $299.2 \pm 135.3$ & $266.9 \pm 117.1$ \\
\hline $\begin{array}{l}\text { Reactor annual GWhr }(t) \\
\text { output }\end{array}$ & $2737 \pm 73$ & $2634 \pm 71$ & $2831 \pm 65$ & $2716 \pm 63$ & $2854 \pm 44$ & $2767 \pm 44$ \\
\hline Reactor reliability & $0.87 \pm 0.00$ & $0.84 \pm 0.02$ & $0.90 \pm 0.02$ & $0.87 \pm 0.02$ & $0.91 \pm 0.01$ & $0.88 \pm 0.01$ \\
\hline
\end{tabular}

${ }^{a}$ The first number is the mean and the second is the standard deviation. Presumably a larger number of years would give more accurate results, but 33 years seem enough to illustrate the method. 
Table 14. Results for example 2 with 33 years of p-ant operation ${ }^{2}$ in mode' 2

\begin{tabular}{|c|c|c|c|c|c|c|}
\hline $\begin{array}{l}\text { Mean time between reactor } \\
\text { failures, days }\end{array}$ & 40 & 40 & 70 & 70 & 100 & 100 \\
\hline $\begin{array}{l}\text { Reactor mean overhaul time, } \\
\text { days }\end{array}$ & 20 & 30 & 20 & 30 & 20 & 30 \\
\hline $\begin{array}{l}\text { Hours per year when outpat } \\
<73 \mathrm{MW}(\mathrm{t})\end{array}$ & 0 & 0 & 0 & 0 & 0 & 0 \\
\hline $\begin{array}{l}\text { Annual average number } \\
\text { forced outages }\end{array}$ & $1-. .1 \pm 3.5^{b}$ & $11.9 \pm 3.7$ & $8.9 \pm 2.9$ & $9.0 \pm 2.3$ & $7.5 \pm 2.3$ & $7.5 \pm 2.9$ \\
\hline $\begin{array}{l}\text { Annual average number reac- } \\
\text { tor outages }\end{array}$ & $7.7 \pm 2.9$ & $8.2 \pm 2.2$ & $5.4 \pm 2.1$ & $5.0 \pm 1.7$ & $3.7 \pm 1.9$ & $3.6 \pm 2.2$ \\
\hline $\begin{array}{l}\text { Annual average MW(t: avail- } \\
\text { able }\end{array}$ & $377.5 \pm 14.3$ & $374.0 \pm 13.8$ & $390.6 \pm 21.1$ & $387.0 \pm 20.3$ & $402.3 \pm 19.2$ & $399.9 \pm 21.9$ \\
\hline $\begin{array}{l}\text { Annual avezage } M W(t) \text { on } \\
\text { outage }\end{array}$ & $26.7 \div 9.8$ & $27.5 \pm 7.4$ & $18.3 \pm 6.5$ & $17.8 \pm 6.1$ & $12.9 \pm 6.1$ & $12.9 \pm 7.2$ \\
\hline $\begin{array}{l}\text { Reactor hours out, annual } \\
\text { average }\end{array}$ & $639.3 \pm 237.4$ & $657.8 \pm 180.1$ & $429.0 \pm 165.2$ & $415.4 \pm 150.7$ & $297.4 \pm 153.9$ & $298.6 \pm 182.1$ \\
\hline $\begin{array}{l}\text { Reactor annual GWhrịt) } \\
\text { output }\end{array}$ & $2736 \pm 86$ & $2631 \pm 63$ & $2810 \pm 54$ & $2715 \pm 54$ & $2858 \pm 58$ & $2763 \pm 62$ \\
\hline Reactor availability & $0.37 \pm 0.03$ & $0.84 \pm 0.02$ & $0.90 \pm 0.0 z$ & $0 . \varepsilon .7 \pm 0.02$ & $0.91 \pm 0.02$ & $0.88 \pm 0.02$ \\
\hline
\end{tabular}

${ }^{a}$ In this mode of operation ro electric power is generated for sale.

$b$ Mean \pm standard deviation. 
for overhaul at the same time - is

$\mathrm{R}=\frac{\text { mean time hetween failures }}{\text { mean time between failures }+ \text { repair time }}$

$\times \frac{\text { mean time between overhauls }}{\text { mean time between overhauls }+ \text { overhaul time }}$

$=\left(\begin{array}{c}\text { fraction of time unit can } \\ \text { run when scheduled to do so }\end{array}\right) \times\left(\begin{array}{l}\text { fraction of time not } \\ \text { scheduled for outage }\end{array}\right)$.

Since the minimum requirement of $73 \mathrm{MW}(t)$ to prevent solidification is between the capacity of one and two boilers, the probability of having $73 \mathrm{MW}(\mathrm{t})$ available from the boilers is (adapted from Section 3.2)

$$
P=1-(1-R)^{5}-5 R(1-R)^{4}=1-(1+4 R)(1-R)^{4} .
$$

Therefore, if the mean time between boiler failures is 150 days, repair time is 2 days, mean time between overhauls is 360 days, and the overhaul time is 30 days, one obtains

$$
R=\frac{150}{152} \times \frac{360}{390}=0.91093
$$

and

$$
P=1-(1+4 \times 0.91093)(1-0.91093)^{4}=0.999681 .
$$

The high probability that $73 \mathrm{MW}(t)$ will be available from the backup boilers helps explain why the Monte Carlo calculation never showed a failure.

\subsection{Example Problem 3}

In this example, the Monte Carlo method is used to determine the reliability of a steam supply system serving a combined refinery and chemical plant - somewhat similar to refinery No. 1 of Ref. 2. That plant plan has been simplified for this example, however, in that any boiler is assumed to be able to supply any load and waste heat recovery boilers have been omitted. The example illustrates the case of a larger 
number of units than in examples 1 and 2. A small reactor [365 $M W(t)$ ] is to supply about one-fourth of the industrial plant's 1400-MW( $t$ ) system load. The 19 existing fossil-fired boilers [total capacity 1559 $M W(t)$ ] are to be retained, with the excess on standby.

The composition and characteristics of the system are shown in Table 15, which is a copy of a part of the computer output; Fig. 9 outlines the plant configuration. The system load was assumed uniform at $1400 \mathrm{MW}(\mathrm{t})$, but a $20 \%$ reduction [280 $\mathrm{MW}(\mathrm{t})$ ] was assumed allowable before an "outage" occurred. This reduction is derived from data provided in line $\mathrm{F}$ of Table 2. Reliability parameters for the nuclear unit were selected on the oamc basis as for example 2, except that. the srheduled reactor outage duration was increased to 45 days. Operating experience is reflected in parameters shown for the fossil-fired units.

Results for 14 years of operation are shown in Table 16 for three values of mean time between reactor failures. Some results include large standard deviations, indicating that a longer operating history would have to be examined if more precise results are sought. The average number of hours per year when thermal output decreased below the

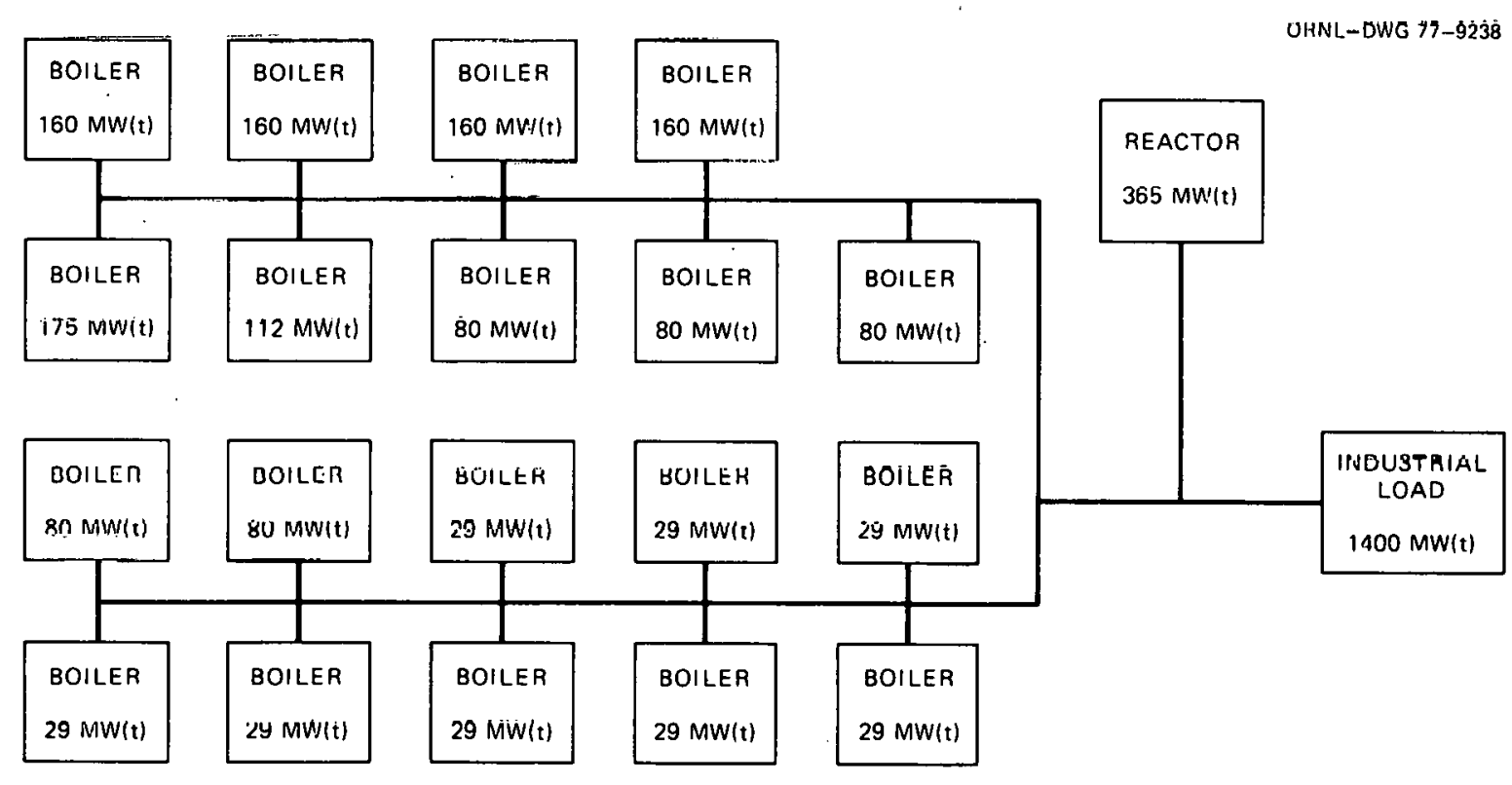

Fig. 9. Plant configuration, example 3. 
Table 15. Characteristics of steam supply plants ${ }^{a}$

\begin{tabular}{|c|c|c|c|c|c|c|c|c|c|c|}
\hline Plant number & 1 & 2 & 3 & 4 & 5 & 6 & 7 & 8 & 9 & 10 \\
\hline Plant name & Reactor & Boiler & Boiler & Boiler & Boiler & Boiler & Boiler & Boiler & Boiler & Boiler \\
\hline Plant type & 1 & 2 & 2 & 2 & 2 & 2 & 2 & 2 & 2 & 2 \\
\hline Capacity, MW(t) & 365.0 & 160.0 & 160.0 & 160.0 & 160.0 & 175.0 & 112.0 & 80.0 & 80.0 & 80.0 \\
\hline Days to first overhaul & 1 & 46 & 106 & 166 & 226 & 286 & 76 & 136 & 196 & 256 \\
\hline $\begin{array}{l}\text { Mean days between } \\
\text { failures }\end{array}$ & $40,70,100$ & 33.0 & 33.0 & 33.0 & 33.0 & 33.0 & 33.0 & 33.0 & 33.0 & 33.0 \\
\hline Mean repair tiqe, days & 3.4 & 2.0 & 2.0 & 2.0 & 2.0 & 2.0 & 2.0 & 2.0 & 2.0 & 2.0 \\
\hline $\begin{array}{l}\text { Mean days between } \\
\text { overhauls }\end{array}$ & 360.0 & 360.0 & 360.0 & 360.0 & 360.0 & 360.0 & 360.0 & 360.0 & 360.0 & 360.0 \\
\hline Overhaul tIme, days & 45.0 & 30.0 & 30.0 & 30.0 & 30.0 & 30.0 & 30.0 & 30.0 & 30.0 & 30.0 \\
\hline $\begin{array}{l}\text { Minimum standby } \\
\text { capacity, MW(t) }\end{array}$ & 0.0 & 0.0 & 0.0 & 0.0 & 0.0 & 0.0 & 0.0 & 0.0 & 0.0 & 0.0 \\
\hline $\begin{array}{l}\text { Probability of partial } \\
\text { shutdown }\end{array}$ & 0.0 & 0.0 & 0.0 & 0.0 & 0.0 & 0.0 & 0.0 & 0.0 & 0.0 & 0.0 \\
\hline Coastdown power time, $\mathrm{hr}$ & 1.000 & 3.000 & 3.000 & 3.000 & 3.000 & 3.000 & 3.000 & 3.000 & 3.000 & 3.000 \\
\hline Buildup power time, hr. & 6.000 & 5.000 & 5.000 & 5.000 & 5.000 & 5.000 & 5.000 & 5.000 & 5.000 & 5.000 \\
\hline Probability of forced. & $0.001 C 42$ & 0.001263 & 0.001263 & 0.001263 & 0.001263 & 0.001263 & 0.001263 & 0.001263 & 0.001263 & 0.00126 \\
\hline
\end{tabular}
outage

\begin{tabular}{|c|c|c|c|c|c|c|c|c|c|}
\hline Plant number & 11 & 12 & 13 & 14 & 15 & 16 & 17 & 18 & 19 \\
\hline Plant name & Boiler & Boiler & Boiler & Botler & Boiler & Boiler & Boiler & Boiler & Boiler \\
\hline Plant type & 2 & 2 & 2 & 2 & 2 & 2 & 2 & 2 & 2 \\
\hline Capacity, MW(t) & 80.0 & 29.0 & 29.0 & 29.0 & 29.0 & 29.0 & 29.0 & 29.0 & 29.0 \\
\hline Days to first overhat 1 & 316 & 1. & 46 & 91 & 136 & 181 & 236 & 271 & 316 \\
\hline $\begin{array}{l}\text { Mean days between } \\
\text { failures }\end{array}$ & 33.0 & 33.0 & 33.0 & 33.0 & 33.0 & 33.0 & 33.0 & 33.0 & 33.0 \\
\hline Mean repalr time, days & 2.0 & 2.0 & 2.0 & 2.0 & 2.0 & 2.0 & 2.0 & 2.0 & 2.0 \\
\hline $\begin{array}{l}\text { Mean days between } \\
\text { overhauls }\end{array}$ & 360.0 & 360.0 & 360.0 & 360.0 & 360.0 & 360.0 & 360.0 & 360.0 & 360.0 \\
\hline Overhaul time, days & 30.0 & 30.0 & 30.0 & 30.0 & 30.0 & 30.0 & 30.0 & 30.0 & 30.0 \\
\hline $\begin{array}{l}\text { Minimum standby ca- } \\
\text { pacity, MW }(t)\end{array}$ & 0.0 & 0.0 & 0.0 & 0.0 & 0.0 & 0.0 & 0.0 & 0.0 & 0.0 \\
\hline $\begin{array}{l}\text { Probability of partial } \\
\text { shutdown }\end{array}$ & 0.0 & 0.0 & 0.0 & 0.0 & 0.0 & 0.0 & 0.0 & 0.0 & 0.0 \\
\hline $\begin{array}{l}\text { Coastdown power time, hr } \\
\text { Bulldup power time, hr } \\
\text { Probability of forced } \\
\text { outage }\end{array}$ & $\begin{array}{l}3.000 \\
5.000 \\
0.001263\end{array}$ & $\begin{array}{l}3.000 \\
5.000 \\
0.001263\end{array}$ & $\begin{array}{l}3.000 \\
5.000 \\
0.001263\end{array}$ & $\begin{array}{l}3.000 \\
5.000 \\
0.001263\end{array}$ & $\begin{array}{l}3.000 \\
5.000 \\
0.001263\end{array}$ & $\begin{array}{l}3.000 \\
5.000 \\
0.001263\end{array}$ & $\begin{array}{l}3.000 \\
5.000 \\
0.001263\end{array}$ & $\begin{array}{l}3.000 \\
5.000 \\
0.001263\end{array}$ & $\begin{array}{l}3.000 \\
5.000 \\
0.001263\end{array}$ \\
\hline
\end{tabular}

$a_{\text {Tota: }}$ system capacity $=1844.0 \mathrm{MW}(t) ;$ load reduction on outage $=280.0$. 
Table 16. Results for 14-year history Monte Carlo reliability analysis (example 3 )

\begin{tabular}{lccc}
\hline & \multicolumn{2}{c}{ Mean time between reactor outages (days) } \\
\cline { 2 - 4 } & 40 & 70 & 100 \\
\hline $\begin{array}{l}\text { Average annual hours of } \\
\text { shortage }\end{array}$ & $101.6 \pm 48.9^{\mathrm{a}}$ & $80.3 \pm 42.1$ & $100.5 \pm 65.5$ \\
$\begin{array}{l}\text { Average annual number } \\
\text { of forced outages }\end{array}$ & $181.1 \pm 8.0$ & $178.1 \pm 8.3$ & $176.3 \pm 8.6$ \\
$\begin{array}{l}\text { Average capacity } \\
\text { availablc }\end{array}$ & $1551.7 \pm 7.0$ & $1565.2 \pm 10.9$ & $1563.0 \pm 9.2$ \\
$\begin{array}{l}\text { Average capacity loss } \\
\text { due to forccd outagco }\end{array}$ & $99.9 \pm 6.8$ & $89.2 \pm 9.2$ & $87.7 \pm 7.0$ \\
$\begin{array}{l}\text { Average reactor output, } \\
\text { GWhr(t) }\end{array}$ & $2479.0 \pm 51.0$ & $2579.0 \pm 77.0$ & $2567.0 \pm 77.0$ \\
$\begin{array}{l}\text { Average annual reactor } \\
\text { outages }\end{array}$ & $7.8 \pm 1.7$ & $4.9 \pm 2.4$ & $4.4 \pm 1.9$ \\
Reactor availability & $0.77 \pm 0.01$ & $0.81 \pm 0.02$ & $0.80 \pm 0.02$ \\
\hline
\end{tabular}

a Numbers represent mean value \pm standard deviation.

acceptable reduced value of $1120 \mathrm{MW}(\mathrm{t})$ ranged on the average from 80 to 102. The standard deviations and these quantities are so large as to mask the sensitivity to the reactor failure rate. The number of occurrences of individual unit forced outages averaged between 176 and 181 per year. The average capacity loss due to forced outages amounted to 6 to $7 \%$. Reactor availability ranged from 0.77 to 0.81 , which is lower than what is believed achievable from fully developed plants.

For comparison, Table 17 shows reliability characteristics calculated for the steam supply system considered in example 3 , but before addition of the reactor. Comparing Table 16 with Table 17 , it can be seen that this average capacity loss due to forced outages is increased by the presence of the reactor - this is primarily because the reactor is more than twice the size of the largest foss1l-fired builer and thus each reactor failure removes a large block of capacity. The annual hours of shortages when the steam system capacity falls below $1120 \mathrm{MW}(t)$ is 
Table 17. Results for 14-year history Monte Carlo reliability analysis for fossil-fired-only case

Averāage annual hours of shortage

9.38.1. \pm 105.7

Average annual number of forced outages

$173.3 \pm 11.1$

Average capacity available, MW(t)

$1266.1 \pm 4.9$

Average capacity loss due to forced outage $b$

$73.2 \pm 4.6$

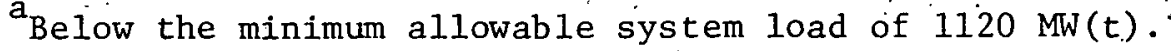

${ }^{b}$ Capacity of forced out units.

much less when the reactor is included, and overall system performance is enhanced by the reactor. Different results would have been obtained if other outage rates and power coastdown or buildup times had been used. The calculation does, however, illustrate how reactor and boiler reliability data can be used to predict their combined performance and to develop some feel for the effect of various unit characteristics on system reliability. 


\section{SUMMARY AND CONCLUSIONS}

Reliability data obtained from reactor operating experience provide a suitable base for estimating the reliability for industrial steam supplied from nuclear reactors. For current-generation large industrial reactors, the reliability data obtained form central station size reactors appear particularly useful. Some care must be taken in using historical data to analyze industrial steam applications. For example, data obtained from central station reactor operations that are to be applied to the analysis of nuclear industrial steam systems may have to be corrected to remove the contribution of power-conversion equipment to unreliability. The state of development of the reactor system under conslderation needs to be considered in predlcting reliabitity. The operating cupcrience with large [ 3700-MW(t)] power reactors was obtained from plants built according to new designs. Due to schedule rnnstraints, follow-on units geileially have been built in accordance with the initial design and thus do not incorporate significant re-engineering that reflects the operating experience that may have been gained with preceding units. This situation will improve as further experience is obtained and plant designs become more fully developed. Plant performance will therefore quite likely improve with time, and this aspect needs to be considered in projecting future reactor reliability.

Relatively little experience has heen obtained with smaller reacturs [ 300 to $400 \mathrm{MW}(t)$ ] and none for second-of-a-kind designs. It seems plausible that the availability of a small reactor built to a standardized design would be superior. A small reactor should experience fewer failures since it comprises fewer components; in addition, refueling requires leco time since fewer fuel elements need to he handled. Maintenance operatiuls requiring plant cooldown and heatup also will be shorter because components w11l be less massive, thus permitting shorter warmup and cooldown perluds.

The calculational methods developed during the study to determine the reliability of industrial energy supply systems powered by nuclear and fossil-fired untts are suitable for analyzing systems of some complexity. The results obtained show that overall reliability of an industrial steam supply system depends on a multiplicity of system characteristics. of 
prime importance are the number and capacity of the various power sources, along with assorted operating characteristics such as outage rates, repair times, and coastdown and startup times. The operating mode of each unit (whether shutdown, hot standby, or on line) can also have a significant effect on system reliability. The nature of the industrial operation, such as allowable reductions in the system load and allowable load coastdown rates, also affect reliability requirements. Thus, it becomes apparent that the reliability of industrial energy supply systems can best be analyzed on a case-by-case basis.

The performance parameters used in the example problems of Section 4 were selected to cover a fairly broad range of reasonable values, and the following conclusions can be drawn from the results.

The results of example 1 give some indication of the availability of a steam supply system fed via a reboiler that in turn is supplied by two reactors, each with sufficient capacity to carry the entire steam load. For this configuration, the steam system availability ranges from 0.86 to 0.95. Tables 1 and 2 , which summarize data obtained in chemical plants and petroleum refineries, show that a sizable fraction of these plants have operated with steam supply availabilities that fall into or below the range of 0.86 to 0.95 cited above. Thus, the two reactor schemes examined above might prove adequate for some industrial applications. The addition of a fossil-fired backup boiler would increase steam availability up to 0.98 to 0.99 , values that are appropriate to industrial processes with more stringent requirements.

The problem treated in example 2 illustrates application of a small industrial reactor as a replacement for an existing industrial steam supply system. Five boilers that were part of the existing facility provide backup steam. For the particular constraints chosen, quite sizable variations in reactor outage rate have minor influence on overall steam reliability. Moderate gains in steam reliability are achieved if the fossil units are kept on line to supply power to a sheddable electric load. Adequate reliability is maintained under ail the conditions examined, and it is clear that multiple fossil-fired units can provide quite adequate backup. This option is particularly attractive for reactor applications at sites 
that already have fossil-fired boilers but where operation must be curtailed because fuel has become scarce or costly. Under these circumstances, the chargeable capital costs for providing backup boilers may be moderate. The cost of fuel consumed is also likely to be a minor factor since fossil fuels would be used to produce only a small fraction of the total amount of energy consumed.

Example 3 showed that the Monte Carlo method can readily handle fairly complex systems that include many variables. Here, a single reactor was assumed to replace about one-fourth of the capacity of an existing fossil-fired industrial steam supply system. For the particular case studied, moderate changes in reactor failure rate had only a minor impact on the overall performance of the steam supply system. Addition of the reactor system significantly reduced the annual hours of steam shortages. 
Appendix A

A. NUCLEAR SYSTEMS FOR INDUSTRIAT, PROCESS ENERGY

A partial survey of the potential market for nuclear industrial energy sources indicates there are major possibilities for process steam applications. It is estimated ${ }^{9}$ that steam at temperatures and pressures available from current-generation light-water reactors (LWRs) could (functionally) replace about $85 \%$ of the steam now generated with fossil fuels in the industries surveyed.

The Midland reactor plant, which is now being built for Consumers Power Company to generate electrical power and furnish process energy (so-called dual-purpose use) to the adjacent Dow Chemical plant, is an example of this approach applied at a very large industrial plant. Since the start of the Midland project, fossil fuels have become increasingly scarce and costly, and thus the relative position of nuclear power economics has improved. As a result, it is now believed that dual-purpose reactor plants (located at sites that allow economical construction of process steam lines) can -provide competitively priced process heat even to industries located up to 10 miles from a reactor station. Thus, it may be practical to furnish process steam to a cluster of industrial plants with an aggregate electrical and process energy demand that warrants operation of a centrally located dual-purpose reactor station.

Another solution would be to use small industrial nuclear reactors [300 to $500 \mathrm{MW}(\mathrm{t})$ ] which would match the load demand of single liarge energy user plants, thus avoiding the institutional problems arising from use of a single utility-owned plant to serve a number of industries. Furthermore, the planning and construction of small reactors could quite likely be accomplished within about two-thirds of the time required for large central station reactors.

In order to provide background for the reader, some of the reactor. systems considered for industrial applications will be briefly described. Two of these are LWR designs, based on current technology, that would be suitable for near-term applications. Two others are advanced high-temperature, gas-cooled, pebble-bed reactor concepts" that probably would not be ready for commercial introduction until the-1990s. 


\section{A.1 Sma11 Pressurized-Water Reactors}

One of the near-term small nuclear reactors available for industrial applications is based on a 313-MW( $t$ ) ship propulsion reactor already developed for the U.S. Maritime Administration. Work on the Consolidated Nuclear Steam Generator (CNSG) for nuclear ship propulsion has been under way at Babcock \& Wilcox Company ${ }^{15}$ since 1959. Some of the unique features of the plant design, including the once-through steam generator housed within the reactor vessel, have already been demonstrated in the Federal German Republic nuclear ship "Otto Hahn," which has operated successfully since 1969. The U.S. Marit1me Connission has conthued lu sponsor work in the areas of design, testing, and evaluation of the CNSG concept, and current efforts are directed toward icebreaker propulsion.

The CNSG design is essentially based on current technology, and relatively little development would be required for process heat applications for up to $365 \mathrm{MW}(t)$. Major reactor parameters are shown in Table $A-1$.

Table A-1. Reactor parameters

Size

System pressure

Core inlet temperature

Core outlet temperature

Maximum thermal output (100\%)

Boiler feedwater temperature

Total steam-generator flow

Steam side design temperature

Steam side operating temperature

Steam side operating pressure

Process steam flow

Process steam temperature

Process steam pressure

Process condensate temperature
$365 \mathrm{MW}(\mathrm{t})$

$15,510 \mathrm{kPa}$ (2250 psia)

$300^{\circ} \mathrm{C}\left(571.6^{\circ} \mathrm{F}\right)$

$319^{\circ} \mathrm{C}\left(606.4^{\circ} \mathrm{F}\right)$

$53 \mathrm{~kW} / \mathrm{m}(16.08 \mathrm{~kW} / \mathrm{ft})$

$204^{\circ} \mathrm{C}\left(400^{\circ} \mathrm{F}\right)$

$189 \mathrm{~kg} / \mathrm{s}\left(1.50 \times 10^{\mathrm{C}} \mathrm{Lb} / \mathrm{hr}^{\circ}\right)$

$343^{\circ} \mathrm{C}\left(650^{\circ} \mathrm{F}\right)$

$281^{\circ} \mathrm{C}\left(5 / 18^{\circ} \mathrm{F}\right)$

$4830 \mathrm{kPa}$ (700 psia)

$183 \mathrm{~kg} / \mathrm{s}\left(1.45 \times 10^{6} \mathrm{lb} / \mathrm{hr}\right)$

$250{ }^{\circ} \mathrm{C}\left(483^{\circ} \mathrm{F}\right)$

$4000 \mathrm{kPa}$ (580 psia)

$121^{\circ} \mathrm{C}\left(250^{\circ} \mathrm{F}\right)$ 
The reactor can be utilized to produce about $1.45 \times 10^{6} \mathrm{lb} / \mathrm{hr}$ of process steam or about $110 \mathrm{MW}(\mathrm{e})$, or a combination of both. Process steam would be produced in a reboiler to provide further isolation between the primary coolant and the industrial processes. The capital cost for a process-steam-producing plant (without interest during construction) amounts to about 100 million 1975 dollars, excluding escalation and interest during construction. Levelized process steam costs ${ }^{16}$ range from $\$ 2.60$ to $\$ 3.40$ (in 1975 dollars) for a variation in the capital fixed charge rate from 15 to $22 \%$.

\section{A.2. Swal1 Pebble-Bed Reactor}

Applications of small, gas-cooled, pebble-bed reactors for industrial energy were evaluated in a study 17 by the General Electric Company under contract to ORNL. This technology is based on the 40-MW( $t$ ) AVR pebble-bed reactor in Germany that has operated successfully with helium reactor exit temperatures up to $950^{\circ} \mathrm{C}\left(1742^{\circ} \mathrm{F}\right)$ with on-line refueling. The study evaluated three distinct pebble-bed reactor concepts designed to furnish process energy to industry: (1) a plant for the production of process steam only, (2) a plant for the production of synthetic gas through methane reforming, and (3) a plant for generating electricity with a helium-driven turbogenerator in addition to producing process steam. The range of power level [200-1000 MW(t)] is compatible with the energy requirements of large chemical, petroleum refining, and primary metals plants.

\section{A.2.1 Process Steam P1ant}

The reactor consists of a cylindrical prestressed concrete pressure vessel containing a graphite reflector assembly, and the core consists of a bed of spherical graphite balls containing the fuel. Fuel is added continuously at the top and removed at the bottom after a residency time of approximately 4.5 years. The reactor coolant, helium gas at about 4000 $\mathrm{kPa}(580 \mathrm{psia})$, flows downward in the same direction as the fuel flow. The reactor delivers $186 \mathrm{~kg} / \mathrm{s}\left(1.48 \times 10^{6} \mathrm{lb} / \mathrm{hr}\right)$ of helium at an exit temperature of $760^{\circ} \mathrm{C}\left(1400^{\circ} \mathrm{F}\right)$. This gas is circulated through three 
steam generators to produce a total of $171 \mathrm{~kg} / \mathrm{s}\left(1.36 \times 10^{6} \mathrm{lb} / \mathrm{hr}\right)$ of superheated steam at $510^{\circ} \mathrm{C}\left(950^{\circ} \mathrm{F}\right)$ and $5860 \mathrm{kPa}(850 \mathrm{psia})$. The steam generators include double tubes and double tubesheets in order to provide a buffer region between the radioactive primary coolant and the process steam. Attractive features of this design include on-1ine refueling (resulting in a' larger'plant factor) and elevated steam conditions that are directly compatible with steam utilization in current industrial plants.

A considerable amount of component development io necerary and $a$ prototype plant would have to be built for the introduction of small commercial pebble-bed reactors. Assuming the project starts in 1977 , prototype plant startup could take place by 1987 , and commercial plant startup around 1990.

Levelized process steam costs for a 365-MW(t) reactor are about $28 \%$ higher than those for the 365-MW(t) PWR discussed previously, thus reflecting the higher capital cost of the pebble-bed reactor. These costs do not reflect the potentially greater value of $510^{\circ} \mathrm{C}\left(950^{\circ} \mathrm{F}\right)$. steam from the pebble-bed reactor relative to steam of on $1 \mathrm{y} 250^{\circ} \mathrm{C}\left(483^{\circ} \mathrm{F}\right)$ from the LWR.

\section{A.2.2 Nuclear Procéss Heat Plant}

The purpose of this plant is to produce reducing gas from the reaction $\mathrm{CH}_{4}+\mathrm{H}_{2} \mathrm{O}+$ heat $\rightarrow \mathrm{CO}+3 \mathrm{H}_{2}$. The energy required to make the reaction proceed is supplied by the reactor, as opposed to use of chemical energy, which is the present industrial method. Since natural gas is used both as feed stock and as heating fuel, the use of nuclear energy essentially doubles the yield of hydrogen from a given àmount of natural gas. The product gas - a mixture of unreacted methane, carbon monoxide, carbon dioxide, hydrogen, and steam - may be treated in many ways as dictated by its ultimate use. These treatments may range from the production of essentially pure hydrogen to the use of the gas mixture in a chemical heat pipe to supply energy at a distant location via the reverse reaction. 
A key difference between this concept and the process steam design is the elevated operating temperature of the reformer plant. The reactor helium exit temperature of $950^{\circ} \mathrm{C}\left(1742^{\circ} \mathrm{F}\right)$ places very stringent limitations on selection of materials. Since metals are currently not ASME qualified for use above $815^{\circ} \mathrm{C}\left(1500^{\circ} \mathrm{F}\right)$, much proof testing will be required to derive. the needed pressure vessel code approvals.

The reactor power of $500 \mathrm{MW}(\mathrm{t})$ is used to generate $27.9 \mathrm{~kg} / \mathrm{s}(455,000$ $\mathrm{lb} / \mathrm{hr})$ of steam at $510^{\circ} \mathrm{C}\left(950^{\circ} \mathrm{F}\right)$ for injection into a double-tube steam reformer. For a methane consumption rate of $8.6 \mathrm{~kg} / \mathrm{s}(6800 \mathrm{lb} / \mathrm{hr})$, reducing gas is produced at a rate of $36.5 \mathrm{~kg} / \mathrm{s}(290,000 \mathrm{lb} / \mathrm{hr})$ at $600^{\circ} \mathrm{C}$ $\left(1110^{\circ} \mathrm{F}\right)$. Levelized costs for the energy produced by the reactor amount to $625 \mathrm{c} / 10^{6} \mathrm{~kJ}\left(659 \mathrm{c} / 10^{6} \mathrm{Btu}\right)$. The high energy cost is partly due to the relatively small power output. By comparison, energy costs for large [3000-MW(t)] pebble-bed reactor application were estimated at only $310 \mathrm{c} /$ $10^{6} \mathrm{~kJ}\left(330 c / 10^{6} \mathrm{Btu}\right)$ in a recent assessment ${ }^{18}$ of VHTR technology. Thus, application of a small pebble-bed reactor for reforming steam may be advantageous, primarily if institutional, geographic, or other considerations rule out product gas supplied by pipeline from a large central. station-size unit.

\section{A.3 Dual-Purpose Station Powered by Two Large PWRs}

The application 19 of large PWRs for industrial energy. is illustratcd in this description of a reactor plant designed to produce electricity for a utility grid and process steam for piping to nearby industries. The reactor station consists of two current-type 3750-MW(t) PWRs and a power conversion system. Prime steam flow amounts to $2000 \mathrm{~kg} / \mathrm{s}\left(16 \times 10^{6}\right.$ $\mathrm{lb} / \mathrm{hr})$ at $318^{\circ} \mathrm{C}\left(603^{\circ} \mathrm{F}\right)$. Process steam. is furnished from a reboiler rather than from the prime steam generators since, in many applications, an intermediate heat transport system may be required to prevent the transfer of contaminants between the reactor systems and the industrial

processes. For the base case, all the steam from one reactor is supplied to a 1200-MW(e) turbogenerator, while steam from the second is split 54/ 46 between a 650-MW(e) turbogenerator and a reboiler capable of generating $6 \times 10^{6} \mathrm{lb} / \mathrm{hr}$ of process steam at $5860 \mathrm{kPa}(850 \mathrm{psia})$ and $274^{\circ} \mathrm{C}$ 
$\left(525^{\circ} \mathrm{F}\right)$. The capacity of the reboiler and the smaller of the turbogenerators could be varied to match different process steam flow rate requirements. For applications requiring lower. process steam pressure and temperature, the smaller generator could be driven by an extraction or back-pressure turbine, with the extraction or exhaust steam going to a reboiler producing steam at more moderate conditions.

For the base case, prime steam at about $317^{\circ} \mathrm{C}\left(603^{\circ} \mathrm{F}\right)$ and $7400 \mathrm{kPa}$ (1075 psia) is supplied to the tube side of the rebollers to generate process steam at $274^{\circ} \mathrm{C}\left(525^{\circ} \mathrm{F}\right)$ and $5860 \mathrm{kPa}(850 \mathrm{psid})$ on the shell side. Steam is generated at a rate of $755 \mathrm{~kg} / \mathrm{s}\left(6 \times 10^{6} \mathrm{lb} / \mathrm{hr}\right)$ in several highpressure reboller units of about $63 \mathrm{~kg} / \mathrm{s}(500,000 \mathrm{lb} / \mathrm{hr})$ capacity each. One backup unit. is needed to maintain full steam flow during reboiling maintenance. Associated with the reboilers are feedwater heaters that heat the condensate from the industrial processes before it is returned to the reboilers. It is anticipated that the reboilers and feedwater heaters would be located at the reactor station so that process steam can be furnished conveniently to a number of dispersed industrial users.

Insulated steel pipes convey the process steam from the reboilers located at the reactor station to the industrial sites utillzing the steam. Assuming pressure drops of 43 to $51 \mathrm{kPa} / \mathrm{km}$ (10 to $12 \mathrm{psi} / \mathrm{mi} .1 \mathrm{e}$ ), a $0.71-\mathrm{m}-\mathrm{diam}(28-\mathrm{ln}$.$) pipe could convey 126 \mathrm{~kg} / \mathrm{s}\left(1 \times 10^{6} \mathrm{~h} / \mathrm{h} / \mathrm{hr}\right)$ of $5860 \mathrm{kPa}$ (abs) (850 psia) steam; a flow of $252 \mathrm{~kg} / \mathrm{s}\left(2 \times 10^{6} \mathrm{lb} / \mathrm{hr}\right) \mathrm{re}-$ quires a diameter of about $0.91 \mathrm{~m}$ (36 i.n.). For steam at $1380 \mathrm{kPa}$ (abs) $(200 \mathrm{psia})$, flows of $126 \mathrm{~kg} / \mathrm{s}\left(1 \times 10^{6} \mathrm{lb} / \mathrm{hr}\right)$ and $252 \mathrm{~kg} / \mathrm{s}\left(2 \times 10^{6} \mathrm{lb} / \mathrm{hr}\right)$ require pipes of $0.91 \mathrm{~m}$ (36 in.) and $1.22 \mathrm{~m}$ (48 in.) diameter, recpective $\perp$.

The required revenue from process steam was oalculated liy laktng the difference between the annual cost and the annual revenue from the sale of electr1c1ty. 'l'he tolal annual production cost for the 1200-MW(e) unit is $\$ 107.8$ million, corresponding to $12.8 \mathrm{mills} / \mathrm{kWhr}$, all expressed in late 1974 dollars. This value is not affected by the dual-purpose nature of the station and is thcrefore considered a fair price for computing the revenue obtained from the sale of electricity. This income amounts to $\$ 58.4$ million per year for the $650-\mathrm{MW}(\mathrm{e})$ unit, leaving $\$ 33.3$ 
million to be obtained from the sale of steam. This is equivalent to a rnst if $77 \mathrm{c} / 10^{6} \mathrm{~kJ}\left(81 \mathrm{c} / 10^{6} \mathrm{Btu}\right)$ of reactor prime steam.

A $15 \mathrm{c} / 10^{6} \mathrm{~kJ}\left(15 \mathrm{c} / 10^{6} \mathrm{Btu}\right)$ cost increment is attributable to the reboiler plant. Total cost of the 5860-kPa (abs) (850-psia) $274^{\circ} \mathrm{C}$ $\left(525^{\circ} \mathrm{F}\right.$ ) process steam therefore amounts to $92 \mathrm{c}$ per million $\mathrm{kJ}$ ( $97 \mathrm{c}$ per million Btu) at the reboiler.

The cost of process steam at lower temperature was derived from cost data 20 for dual-purpose LWRs. Table A-2 combines the steam production and transport costs, giving the cost for 1380-, 3450-, and 5860-kPa (abs) (200-, 500-, and 850-psia) saturated steam delivered to industrial users located at sites up to $16 \mathrm{~km}$ (10 miles) from the power station. The cost of delivered process steam ranges from 78 to $191 \mathrm{c} / \mathrm{million} \mathrm{kJ}$ ( 82 to $201 \mathrm{c} / 10^{6} \mathrm{Btu}$ ), depending on the particular steam pressure, flow rate, and conveyance distance.

Table A-2. Cost $\left(c / 10^{6} \mathrm{~kJ}\right)$ of process steam as a function of conveyance distance ${ }^{a}$

\begin{tabular}{|c|c|c|c|c|c|c|}
\hline \multirow{2}{*}{$\begin{array}{l}\text { Steam flow, } \mathrm{kg} / \mathrm{s} \\
(1 \mathrm{~b} / \mathrm{hr}) \\
\text { Pressure, } \mathrm{kPa} \\
\text { (psia) }\end{array}$} & \multicolumn{3}{|c|}{$\begin{array}{c}126 \\
(1,000,000) \\
\end{array}$} & \multicolumn{3}{|c|}{$\begin{array}{c}250 \\
(2,000,000) \\
\end{array}$} \\
\hline & $\begin{array}{l}1380 \\
(200)\end{array}$ & $\begin{array}{l}3450 \\
(500)\end{array}$ & $\begin{array}{l}5860 \\
(850)\end{array}$ & $\begin{array}{l}1380 \\
(200)\end{array}$ & $\begin{array}{l}3450 \\
(500)\end{array}$ & $\begin{array}{l}5860 \\
(200)\end{array}$ \\
\hline \multicolumn{7}{|l|}{$\begin{array}{l}\text { Pipeline length } \\
\text { [km (miles)] }\end{array}$} \\
\hline $\begin{array}{l}0(0) \\
4.8(3.0) \\
9.6(6.0) \\
16.1(10.0)\end{array}$ & $\begin{array}{r}78 \\
101 \\
126 \\
156\end{array}$ & $\begin{array}{r}88 \\
114 \\
139 \\
173\end{array}$ & $\begin{array}{r}92 \\
120 \\
151 \\
189\end{array}$ & $\begin{array}{r}78 \\
96 \\
119 \\
146\end{array}$ & $\begin{array}{r}88 \\
110 \\
132 \\
161\end{array}$ & $\begin{array}{r}92 \\
117 \\
142 \\
176\end{array}$ \\
\hline
\end{tabular}

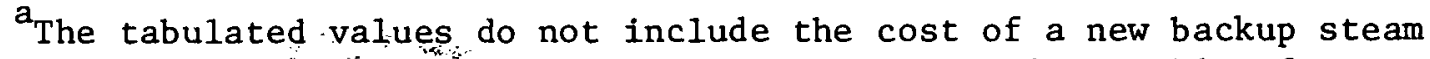
supply. Provision of an oil-fired standby steam supply capable of providing $25 \%$ of norma 1 flow would Increase the cost of $1380-\mathrm{kPa}$ process steam by about $3 \mathrm{c} / \mathrm{million} \mathrm{kJ}$. The corresponding values for $3450-$ and $5860 \mathrm{Am} \mathrm{Pa}$ steamare 15 and $18 \mathrm{c}$, respectively. To convert to $\mathrm{s} / 10^{6} \mathrm{Btu}$, multiply by 1,055 .

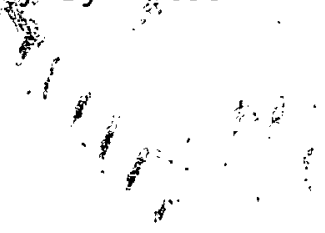


THIS PAGE

WAS INTENTIONALLY

LEFT BLANK 


\author{
Appendix B \\ GLOSSARY FROM OPERATING UNITS STATUS REPORT, \\ LICENSED OPERATING REACTORS ${ }^{3}$
}

Available

Available hours

Date of commercial operation

Design electrica1 rating, MW(e)

Gross electrical energy generated

Gross electrical power MW (e)

Gross hours in reporting period

Gross thermal power

Gross thermal energy. generated

Hours generator on line (service hours)

Licensed or currently authorized power level

Maximum dependable capacity
Status of unit or major piece of equipment which is capable of service whether or not it is actually in service.

Service hours + reserve shutdown hours.

Date unit declared by utility-owner to be available for the regular production of electricity; usually related to satisfactory completion of qualification tests as specified in the purchase contract and to accounting policies and practices of utility.

Nominal net electrical output of the unit specified by the utility and used for the purpose of plant design.

Gross electrical power times gross hours in reporting period.

Electrical output of the unit measured at the output terminals of the turbine generator.

24 times number days in month.

Thermal output of the nuclear steam supply system expressed in megawatts.

Gross thermal power times gross hours in reporting period.

Total number of hours unit operated with breakers closed to station bus.

Maximum thermal power of the reactor, expressed in megawatts; authorized by the NRC.

Dependable main-unit capacity (net), winter or summer, whichever is smaller. The maximum dependable capacity often differs from the unit Design Electrical Rating because the unit efficiency may vary during the year due to cooling water temperature variations. The Net Maximum Dependable Capacity is the gross electrical output, as measured at the output terminals of the turbine generator during the most restrictive seasonal conditions (usually summer), less the normal station service loads. The Maximum Dependable Capacity can be used to compute the unit capacity factor. 
Net electrical energy generated (output)

Operating availability

Period hours

Reactor availability

factor (aka. operating availability)

Reactor service factor

Reporting period

Reserve shutdown

Reserve shutdown hours

Restricted power level MW (e) - net

Scheduled outage

Service hours

Startup and power ascension test phase

Unit availability factor

Unit capacity factor

(using $\mathrm{MDC}$ )

Unit capacity factor

[using desigin MW(e)]

Unit forced outage rate

Unit service factor
Gross electrical output of the unit measured at the output terminals of the turbine generator minus the normal station service loads.

See Reactor Availability Factor.

See Gross Hours in Reporting Period.

$\frac{\text { Reactor available hours }}{\text { Gross hours in reporting period }} \times 100$

$\frac{\text { Hours reactor critical }}{\text { Gross hours in reporting period }} \times 100$

Calendar month for which data are presented, unlees otherwise specified.

Removal of unit from service for economic or oimilar roacone, but available for operatinn:

Reserve shutdown times number of hours.

Maximum net electrical generation to which the unit is restricted because of the malfunction of equipment, other conditions that may exist, or a direction by NRC.

Planned removal of a unit from service for refueling, inspection, and/or general overhaul of one or more major equipment groups.

See Hours Generator On Line.

Period following initial criticality during which the unit is tested at successively higher levels, culminating with operation at full power for a silsralned perlod and coulpletion of warranty runs. Following this phase, the unit is generally considered by the utillty to be avallable for commercial operation.

$\frac{\text { Unit available hours }}{\text { Cros3 hours in reporting period }} \times 100$
$\frac{\text { Tnta1 net generation (MWhr) }}{\text { Period hours } \times \text { max. depend. capacity }}$
$\frac{\text { Total net genteatió (MWhr) }}{\text { Perind hnura } \times \text { dcoign elec, rating }}$
$\frac{\text { Forced outage hours }}{\text { Hr generator on line }+ \text { forced outage hr }} \times 100$
$\frac{\text { Hours generator on linc (acrvice hours) }}{\text { Period hours }} \times 100$

NOTE: Do not include reserve shutdown hours in calculation. 
Appendix C

DEFINITIONS OF TERMS USED IN THE ANNUAL REPORTS ON EQUIPMENT AVAILABILITY PUBLISHED BY EEI ${ }^{6}$

\section{A. EQUIPMENT DEFINITIONS}

1. Nonheader unit

Unit in which a single boiler is connected solely and independently to a given turbine generator.

2. Header unit

Unit in which the turbine generator is not solely and independently connected to single boiler.

3. Major equipment

Major group of equipment within a unit, such as: boiler, reactor, generator, steam turbine, condenser.

4. Component

Part within a "major equipment" group, such as superheater tube, governor, buckets, boiler feed pump.

5. Maximum dependable The dependable main-unit capacity winter capacity (MDC) or summer, whichever is smaller.

B. OPERATION AND OUTAGE DEFINITIONS

1. Available

2. Base loading

3. Cranking loading

4. Cycling loading

5. Economy outage

6. Forced outage

7. Forced partial outage

8. Maintenance outage
The status of a unit or major piece of equipment which is capable of service, whether or not it is actually in service.

When a unit is generally run at or near rated output.

When a unit is generally shut down on standby for auxiliary power during emergency.

When a unit is generally run but at a load which varies widely with system demand.

(See Reserve Shutdown).

The occurrence of a component failure or other condition which requires that the unit be removed from service immediately or up to and including the very next weekend.

The occurrence of a component failure or other condition which requires that the load on the unit be reduced $2 \%$ or more immediately or up to and including the very next weekend.

The removal of a unit from service to perform work on specific components which could have been postponed past the very next weekend. This is work done to prevent a potential forced outage and which could not be postponed from season to season. 
9. Noncurtailing equipment outage

10. Nonoperating equipment test

11. Outage cause

12. Peak loading

13. Planned outage

14. Reserve shutdown

15. Scheduled partial outage

16. Unavailable

\section{C. 'I'IME DEFINITIONS}

1. Available hours (AH)

2. Demand period

3. Economy outage hours (see Reserve shutdown hours) (TEOH)
The removal of a specific component from service for repair, which causes no reduction in unit load or a reduction of less than $2 \%$.

A scheduled test or required operation of a backup system which is not normally operating.

A component failure, preventive maintenance, or other condition which requires that the unit or a component be taken out of scrvice or run at reduced capacity.

When a unit is generally shut down and is run only, during high demand periods.

The relluval of a unte from servire tor ins spection and/or general overhaul of one or more major equipment groups. This is work which is usually scheduled weil in advance (e.g., annual boiler overhaul, five-year turbine overhaul).

The removal of a unit from service for economy or similar reasons. This status continues as long as the unit is out but available for operation.

The occurrence of a component failure or other condition which requires that the lual un the unit be ieduced 2\% or more but where this reduction could be postponed past the very next weekend.

The status of any major piece of equipment which renders it inoperable because of the failure of a component, work being performed or other adverse condition.

The time in hours during which a unit or major cquipment is available; $\underline{\mathrm{SH}}+\mathrm{RSH}$.

Tle Llme 1,ncerval each day which is the period of maximum demand on a particular system.

The theoretical value of economy outage hours (TEOH) is the difference between available hours and service hours. If the TF.OH differs by less than $1 \%$ with the economy outage hours reported at the end of the year, they are considered equal and flagged.with code 1 . If the difference is 


\section{Forced outage hours ( $\mathrm{FOH})$}

5. Forced partial outage hours (FPOH)

6. Hours waiting (HW)

7. Maintenance outage hours (MOH)

8. Period hours (PH)

9. Planned outage hours $(\mathrm{POH})$

10. Reserve shutdown hours (RSH)

11. Scheduled partial outage hours (SPOH)

12. Service hours (SH)

13. Unit years (UY)

14. Work (manhours worked) (MH) more than $1 \%$, but less than $10 \%$, they are flagged with code 3 ; but the reported economy outage hours are still used. However, if the difference is greater than $10 \%$, the calculated value $\mathrm{TEOH}$ is used, and code 2 is a flag that economy outage hours have been derived.

The time in hours during which a unit or major equipment was unavailable due to a forced outage.

The time in hours during which a unit or major equipment is unavailable for full load due to a forced partial outage.

That portion of time for any outage during which no work could be performed. This includes time for cooling down equipment and shipment of parts. This is time that could not be affected by a change in work schedule or the number of men worked.

The time in hours during which a unit or major equipment is unavailable due to a maintenance outage.

The clock hours in the period under consideration (generally one year).

The time in hours during which a unit or major equipment is unavailable due to a planned outage.

Reserve shutdown duration in hours.

The time in hours during which a unit or major equipment is unavailable for full load due to a scheduled partial outage.

The total number of hours the unit was actually operated with breakers closed to the station bus.

This term is the common denominator used to normalize data from units of the same type with different lengths of service. The following example contains $20 \mathrm{UY}$ of experience from 4 units.

$\begin{array}{lllllc}\text { Unit } & \text { A } & \text { B } & \text { C } & \text { D } & 4 \\ \text { Years in service } & 8 & 3 & 7 & 2 & 20\end{array}$

The total number of manhours worked on or off site to accomplish repairs. 


\section{EQUATIONS}

1. Average forced outage duration

2. Capacity factor

3. Component outage severity index

4. Equivalent forced outage rate (EFOR) (for each forced partial outage, and equivalent full load outage duration is calculated to include the effect of partela 1 as well as full forced outages on the forced outage rate)

5. Forced outage incident rate

6. Forced outage rate

7. Scheduled outage rate

8. Forced outage rätio

9. Operating availability

10. Equivalent availability

11. Output factor

12. Service factor
(Summation of $\mathrm{FOH}$ )/(number of forced outages).

[ (Total gross generation in MWhr) $/(\mathrm{PH} \times$ maximum dependable capacity)] $\times 100$.

The average number of forced outage hours of a specific component per incident.

EFOR is calculated as follows:

$\mathrm{TE}=\mathrm{FPOH}(\mathrm{CR} / \mathrm{CF})$

where:

$\mathrm{TE}$ is equivalent forced outage time,

$\mathrm{CR}$ is size of reduction or derating from full load,

CF is rated capacity.

Then:

$\mathrm{EFOR}=100 \times[\mathrm{TF}+\mathrm{TES}) /(\mathrm{TO}+\mathrm{TF}+\mathrm{TAS}+$ TPS) j,

where

TF is total full forced outage time,

TO is total operation time at $100 \%$ capability,

TAS is sum of actua $\perp$ torced partial ourage times,

TES is sum of equivalent forced outage times,

TPS is sum of equivalent scheduled partial operating times.

[(Forced incidents)/(forced + maintenance

+ planned incidents $) \times 100$.

$[\mathrm{FOH} /(\mathrm{SH}+\mathrm{FOH})] \times 100$.

$[\mathrm{SOH} /(\mathrm{SH}+\mathrm{SOH})] \times 100$.

[FOH/(Lotal unavailable hours) $] \times 1.00$.

$[\mathrm{AH} / \mathrm{PH}] \times 100$.

$[\mathrm{SH}-(\mathrm{EFOH}+\mathrm{ESOH})] / \mathrm{PH}$.

(Total gross generation in MWhr) $\times 100 /$ $(\mathrm{SH} \times \mathrm{MDC})$

$[\mathrm{SH} / \mathrm{PH}] \times 100$. 
13. Relative mechanical availability (RMA)
RMA is a form of operating availability adjusted to show relative effort. The prime assumption is that most outage time is affccted by work schedules and crew sizes. RMA uses an adjusted outage time (AOT) based on effort. Manhours worked is a measure of effort which is reasonably independent of work schedules and crew sizes. Manhours worked (MH) divided by a standard work force (SWF) gives a derived time worked based on effort. If we assume a round-theclock schedule, then this derived time worked is almost a derived outage time based on effort. The difference is the amount of outage time which is independent of effort called Hours Waiting (HW). See Appendix C-6.* An arbitrary assumption of ten men for the standard work force gives:

$\mathrm{AOT}=\mathrm{HW}+\mathrm{MH} / 10$

Then substituting AOT for outage time in the equation for operating availability gives:

$\mathrm{RMA}=[(\mathrm{PH}-\mathrm{AOT}) / \mathrm{PH}] \times 100$ $=[[\mathrm{PH}-(\mathrm{HW}+\mathrm{MH} / 10)] / \mathrm{PH}\} \times 100$.

Reporting these data is optional.

*Refers to Ref. 3. 
is

THIS PAGE

WAS INTENTIONALLY

LEFT BLANK 


\author{
Appendix D \\ DIFFERENCES IN DEFINITIONS USED IN \\ NRC AND EEI DATA DASES ${ }^{h}$
}

EEI and NRC definitions of availability and capacity factors are similar, but recognizable differences exist which must be evaluated for accurate comparisons. Uperating availability as defined by EEI is

$$
\frac{\text { Available hours } \times 100}{\text { Period hours }}
$$

where available hours = the time in hours during which a unit or major equipment is available. This includes both service hours with breakers to the system but closed and reserve shutdown hours during which the unit is shut down but available for service. Period hours $=$ the clock hours in the period under consideration.

As defined by the NRC, unit availability factor is

$$
\frac{\text { Time generator was on line }(\mathrm{hr}) \times 100}{\text { l'ime in the period }(\mathrm{hr})}
$$

where time generator was on line = only the time the generator was supplying power to the system. Period hours $=$ the clock hours in the period under consideration.

The EEI definition will give a higher availability factor since it takes into account time the unit could have been used but was not. The NRC value, which does not take reserve shutdown hours into account, typically yields availabilities which are 1 to 3 percentage points lower than the EEI values.

Unit capacity factor as defined by both EEI and NRC is "the quotient of the actual net electrical energy output produced by the unit in a given period, divided by the maximum net electrical energy output the unit would have produced if operated at the maximum dependable capacity for the entire period, expressed as a percent."

Maximum dependable capacity (MDC) is "the gross electrical output as. measured at the output terminals of the turbine-generator during the mnst restrictive seasonal conditions, less the normal service loads." 
As a result of the manner in which unit capacity factor is defined, recorded values may vary on a monthly basis (and even exceed 100\%) solely due to environmental considerations. NRC also reports a capacity factor based on the design rating of the unit turbine. 
REFERENCES

1. T. D. Anderson et al., An Assessment of Industrial Energy Options Based on Coal and Nuclear Systems, ORNL-4995 (July 1975).

2. W. G. Sullivan and T. M. West, Process Energy Reliability Requirements for Selected Industries, ORNL/TM-5428 (September 1976).

3. Operating Units Status Report, Licensed Operating Reactors, NUREG0020-7.

4. Evaluation of Nuclear Power Plant Availability, U.S. Atomic Energy Commission Publication 00E-ES-001 (January 1974).

5. L. E. Minnick, "Operating Experience with. Light Water Reactors in the U.S.A.," presented at the European Nuclear Conference, Paris, France, Apr. 21, 1975.

6. Edison Electric Institute, Report on Equipment Availability for the Ten-Year Period, 1965-1974, Publication No. 75-50 (November 1975).

7. M. E. Lapides and E. Zebroski, Use of Nuclear Plant Operating Experience to Guide Productivity Improvement Programs, EPRI-SR-26-R, p. 20 (November 1975).

8. Federal Energy Administration, A Report on Improving the Productivity of Electric Power Plants, prepared by FEA Inter-agency Task Force on Powerplant Reliability, Washington, D.C. (March 1975).

9. R. W. Barnes, The Potential Industrial Market for Process Heat from Industrial Reactors, prepared for ORNL by Dow Chemical Co., ORNL/TM5516 (July 1976).

10. Final Report of NSF Grant No. OEP74-20242, Energy Industrial Center Study, prepared by the Dow Chemical Co. (June 1975).

11. U. G. Knight, Power Systems Engineering and Mathematics, Pergamon Press, 1972 .

12. S. Finger, Modeling Conventional and Pumped Hydro-Electric Energy Using Booth-Baleriaux Probabilistic Simulation, Report No. MIT-EL 75-009 WP (August 1975).

13. J. C. Turnage et a1., The Oak Ridge System Integration Model (ORSIM) for Optimization of Utility Generation Planning, ORNL/TM-4506 (October 1975).

14. D. S. Joy and R. T. Jenkins, A Probabilistic Model for Estimating the Operating Cost of an Electric Power Generating System, ORNL/ TM-3549 (October 1971). 
15. R. W. Dickinsön, S. H. Esleeck, and J. W. Lemon, "Nuclear Maritime An Economic Revival," paper presented at Spring Meeting of the Society of Naval Architects and Marine Engineers, Williamsburg, Va., May 24-27, 1972 .

16. A Small Pressurized Water Reactor for Process Energy - Plant Costs and Design Studies, BAW-1428/ORNL-Sub-4390-2, prepared by Babcock and Wilcox under contract to the Oak Ridge National Laboratory (June 1976).

17. Small Nuclear Process Heat Plants (SNPH) Using Pebble-Bed Reactors, GEEST 75-001, prepared by the General Electric Company for the Oak Ridge National Laboratory (November 1975).

18. I. Spiewak et al., Assessment of Very High-Temperature Reactors in Process Applications, ORNL/TM-5242 (Nov. 16, 1976).

19. O. H. Klepper, "Nuclear Dua1-Purpose Plants for Industrial Energy," presented at Eleventh Inter Society Energy Conservation Engineering Conference, Stateline, Nev., Sept. 12-17, 1976.

20. C. C. Haws to O. H. Klepper, Oak Ridge National Laboratory, personal communication. 
ORNL/TM-5837

INTERNAL DISTRIBUTION

$$
\begin{aligned}
\text { 1. } & \text { T. D. Anderson } \\
\text { 2. } & \text { S. Baron } \\
\text { 3. } & \text { T. E. Cole } \\
\text { 4. } & \text { W. E. Cooper } \\
\text { 5. } & \text { F. L. Culler } \\
\text { 6. } & \text { J. G. Delene } \\
\text { 7. } & \text { G. G. Fee } \\
\text { 8. } & \text { M. J. Goglia } \\
\text { 9. } & \text { J. F. Harvey } \\
\text { 10. } & \text { J. E. Jones } \\
\text { 11. } & \text { M. A. Karnitz } \\
\text { 12-15. } & \text { O. H. Klepper } \\
\text { 16. } & \text { M. Levenson }
\end{aligned}
$$

17. M. Olszewski

18. H. Postma

19. M. W. Rosenthal

20. D. Scott

21. M. R. Sheldon

22. M. J. Skinner

23. I. Spiewak

24. D. B. Trauger

25. W. J. Wilcox

26-27. Central Research Library

28. Document Reference Section

29-31. Laboratory Records Dept.

32. Laboratory Records (RC)

EXTERNAL DISTRIBUTION

33. S. L. Adams, Gulf States Utilities, P.0. Box 2951, Beaumont, Tex. 77704

34. Seymour Alpert, Electric Power Research Institute, 3412 Hillview Ave., Palo Alto, Calif. 94304

35. R. W. Barnes, Dow Chemical Company, 2040 Dow Center, Midland, Mich. 48640

36. D. J. Blickwede, Bethlehem Steel Corp., Bethlehem, Pa. 18016

37. R. B, Fancher, Planning and Research, Pacific Gas and Electric Company, 77 Beale Street, San Francisco, Calif. 94106

38. M. W. Golay, Dept. of Nuclear Engineering, Massachusetts Institute of Technology, 138 Albany St., Cambridge, Mass. 02139

39. Leon Green, Jr., MITRE Corp., Westgate Research Park, McLean, Va. 22101

40. Tom Gross, Office of Conservation and Environment, Federal Energy Agency, 12 Pennsylvania Ave., Washington, D.C. 20461

41. H. L. Harkins, Power Systems Engineering, Inc., P.0. Box 19398, Houston, Tex. 77024

42. A, E. Kakretz, Manager, Gas Reactor Development, General Electric Co., Fairfield, Conn. 06430

43. A. T. McMain, General Atomic Company, P.0. Box 81608, San Diego, Calif. 92138

44. M. J. McNelly, General Electric Co., 175 Curtner Ave., Mail Stop 540, San Jose, Calif. 95125

45. H. G. MacPherson, Dept. of Nuclear Engineering, University of Tennessee, Knoxville, Tenn. 37916

46. George Story, Research and Technology Division, U.S. Army Facilities Engineering Support Agency, Fort Belvoir, Va. 22060 
47. J. G. Prather, Energy Research and Development Administration, 20 Massachusetts Ave., Washington, D.C. 20545

48. W. S. Ku, Public Service Electric and Gas Co., 80 Park Place, Newark, N.J. 07101

49. J. Karkheck, Brookhaven National Laboratory, Upton, L.I., N.Y. 11973

50. J. L. Renzetti, Naval Nuclear Power Unit, 13101 Pelfrey Lane, Fairfax, Va. 22030

51. R. A. Shade, Boise Cascade Corp., One Jefferson Square, Boise, Idaho 83728

52. W. R. Smith, Power Generation Group, Babcock and Wilcox Company, P.0. Box 1260, Lynchburg, Va. 24505

53-56. W. G. Sullivan, Dept. of Tndustrial Engineering, North Carolina State University, Box 5511, Raleigh, N.C. 27607

57. R. L. Thompson, Federal Energy Administration, 1200 Pennsylvania Ave:, Washlngron, D.C. 20461

58. Leonard Topper, Energy Research and Development Administration, 20 Massachusetts Ave., Washington, D.C. 20545

59. Seth Tuttle, Program Manager (SIA), National Science Foundation, 1800 G Street NW, Washington, D.C. 20550

60. A. M. Weinberg, Oak Ridge Associated Universities, P.0. Box 117, Oak Ridge, Tenn. 37830

61. R. W. Wendes, Amoco Oil Co., M.C. 1105, Box 6110Z, Chicago, I11. 60680

62. J. Crowley, United Engineers and Constructors, Inc., 1401 Arch Street, Philadelphia, Pa. 19105

63. Director, Division of Nuclear Research and Applications, Energy Research and Development Administration, Wachington, D.C. 20545

64-73. W. F. Savage, Division of Nuclear Research and Applications, Energy Research and Development Administration; Washingtüi, D.C. 20545

74. K. O. Laughon, Division of Nuclear Research and Applications, Energy Research and Development Administration, Washington, D.C. 20545

75. Director, Reactor Division, ERDA, ORO

76. Research and Technical Suppnrt Division, ERD ; , ono

77-100. Industrial Contributors

101 127. Techulcal Information Center, ERDA, ORO 